[Vol. 128:1094

\title{
COMMENTS
}

\section{CAMPAIGN FINANCING OF INTERNAL UNION ELECTIONS}

Until 1959, internal union elections were conducted free of federal interference. ${ }^{1}$ In that year, Congress, prompted by reports of "shameful and unsavory" 2 activities within the labor movement, enacted the Labor-Management Reporting and Disclosure Act of 1959 (LMRDA). ${ }^{3}$ The Act legitimated federal intervention in internal union affairs, sparking an immediate torrent of commentary ${ }^{4}$ which has continued to this day. ${ }^{5}$

The regulation of "employer" ${ }^{\circ}$ campaign contributions in union elections is one of the most recent issues to emerge in the

1 State regulation of union elections was a possibility, but enactment of such legislation was rare. See Rezler, Union Elections: The Background of Title IV of LMRDA [hereinafter cited as Rezler, Elections], in SYMPosrom on LMRDA 475, 476-82 (R. Slovenko ed. 1961) [hereinafter cited as Srmposiom]; Comment, The Problem of Union Corruption and the Labor-Management Reporting and Disclosure Act of 1959, 38 TEx. L. REv. 468, 484-85 (1960) [hereinafter cited as Union Corruption].

2 Senate Selegt Comm. on Improper Activities in the Labor or Management FIEdd, INTERTM Report, S. Rep. No. 1417, 85th Cong., 2d Sess. 3 (1958) [hereinafter cited as McClexidan Conom. Rep.]. See generally, e.g., J. Hutchinson, The Imprerfect Union (1970); R. Kennedy, The Enemy Within (1960); J. McClellan, Crume Wrihout Punismanent (1962); see also Senate Sertect Comm. on Improper activities in the Labor or Management Field, Final Reporx, S. Rep. No. 1139, 86th Cong., 2d Sess., pt. 3 (1960); Senate Select Comam. on

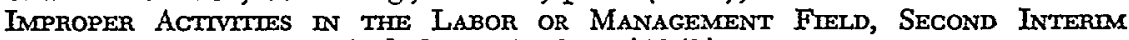
REPort, S. Rep. No. 621, 86th Cong., 1st Sess. (1959).

3 Pub. L. No. 86-257, 73 Stat. 519 (1959) (codified at 29 U.S.C. $\$ \$ 401-531$ (1976)) (sometimes referred to as the Landrum-Griffin Act).

4 See, e.g., 13 N.Y.U. CoNF. LAB. (1960); SYMposium, stipra note 1; Aaron, The Labor-Management Reporting and Disclosure Act of 1959 (pts. 1 \& 2), 73 HARv. L. Rev. 851, 1086 (1960); Cox, Internal Affairs of Labor Unions under the Labor Reform Act of 1959, 58 MrcH. L. Rev. 819 (1960); Symposium, The LaborManagement Reporting and Disclosure Act of 1959, 54 Nw. U. L. Rev. 659 (1960); Comment, Union Corruption, supra note 1.

5 See, e.g., J. Bellace \& A. Berkowtrz, The Landrum-Griffin Act (1979) [hereinafter cited as J. BenLace]; D. McLaughuin \& A. Schoomaker, The LanDRUM-GRUFFIN ACT AND UNION DEMOCRACY (1979) [hereinafter cited as D. Mclaugrinds]; Bellace, Union Trusteeships: Difficulties in Applying Sections 302 and 304(c) of the Landrum-Griffin Act, 25 AM. U. L. Rev. 337 (1976); Fox \& Sonenthal, Section 301 and Exhaustion of Intra-Union Appeals: A Misbegotten Marriage, 128 U. PA. L. Rev. 989 (1980); James, Union Democracy and the LMRDA: Autocracy and Insurgency in National Union Elections, I3 HaRv. C.R.C.L. L. Rev. 247 (1978); Kratzke, Fiduciary Obligations in the Internal Political Affairs of Labor Unions under Section 501(a) of the Labor-Management Reporting and Disclosure Act, 18 B.C. InDus. \& CoM. L. REv. 1019 (1977).

6 The terms "employer" and "outsider" are used interchangeably throughout this Comment. If construed broadly enough, the term "employer" could include 
continuing interpretation of the LMRDA. The Act flatly proscribes both union and employer contributions; its broad, unequivocal language is deceptively clear. ${ }^{7}$ For years, in fact, the courts routinely prohibited the use of union funds to promote the candidacy of a contender, usually the incumbent, ${ }^{8}$ for union office. The use of employer funds, on the other hand, was usually ignored ${ }^{9}$ -probably because challengers, those who relied most on outside support, rarely won elections. ${ }^{10}$

In the last year, however, the federal courts have been forced to confront directly the statutory proscription of use of employer moneys in union campaigns. ${ }^{11}$ New questions have emerged: Who -outside the union-can contribute to a union election? How broadly should the term "employer" be construed? Do outsiders have a constitutional right to express their support for a union candidate through campaign contributions? And finally, if the courts do opt for an extremely broad interpretation of the term "employer," how will union election campaigns be equitably financed?

virtually any outsider sufficiently wealthy to make a meaningful contribution. See James, supra note 5, at 283; Rauh, Outsiders' Assistance in Union Elections, N.Y. Times, Jan. 17, 1977, at 25, col. 3.

7 Section $401(\mathrm{~g})$ of the LMRDA reads:

No moneys received by any labor organization by way of dues, assessment, or similar levy, and no moneys of an employer shall be contributed or applied to promote the candidacy of any person in any election subject to the provisions of this subchapter. Such moneys of a labor organization may be utilized for notices, factual statements of issues not involving candidates, and other expenses necessary for the holding of an election.

29 U.S.C. $\$ 481(\mathrm{~g})$ (1976).

The session law differs slightly from the Code. The former bars contributions "in an election subject to the provisions of this title." Pub. L. No. 86-257, $\$ 401(\mathrm{~g})$, 73 Stat. 519, 533 (1959) (emphasis added).

8 See notes 93-107 infra \& accompanying text.

O See, e.g., Senate Comm. on Labor and Public Werfare, Labor-Management Reporting and Disclosure Act of 1959, S. Rep. No. 187, 86th Cong., 1st Sess. 4 [hereinafter cited as SENATE LABOR CoMM. Rep.], reprinted in [1959] U.S. Code Cong. \& AD. News 2318, 2320, also reprinted in I NLRB, Legrslativis History of the Labor-Management Reporting and Disclosure ACt of 1959 397, 400 (1959) [hereinafter cited as LEGIS. Hist.]; note 168 infra.

10 Mere violation of $\$ 401(\mathrm{~g})$ is insufficient to void election results. The court must find that the violation "may have affected the outcome of an election." LMRDA, $\$ 402(\mathrm{c}), 29$ U.S.C. $\$ 482(\mathrm{c})$ (1976) (emphasis added). See Beaird, Union Officer Election Provisions of the Labor-Management Reporting and Disclosure Act of 1959, 51 VA. L. REv. 1306, 1331-35 (1965). Thus, if the challenger has accepted employer funds and lost, the violation will not be challenged. Further, if the incumbent has accepted funds and won, the challenger is unlikely to file a complaint because he too "has usually received some form of outside support and does not want a ruling on the scope of the prohibition." James, supra note 5, at 282.

11 See notes 26-41 infra \& accompanying text. 
This surge of interest in outsider support of union elections is not surprising. Watergate made it painfully clear to the American public that money and politics often mix-with dangerous consequences. ${ }^{12}$ In addition, a series of hotly contested and widely publicized union leadership races have dramatically raised the question of equitable union campaign financing. The ascendancy of I.W. Abel of the United Steelworkers in $1965,{ }^{13}$ the defeats of James B. Carey and W.A. "Tony" Boyle, presidents of the Electrical Workers and Mineworkers unions, respectively, ${ }^{14}$ and most recently, the bitter 1977 battle between Lloyd McBride and Edward Sadlowski of the Steelworkers, ${ }^{15}$ all provoked accusations of outside employer help. The last campaign was followed widely by the press, ${ }^{16}$ and even inspired a sparring match on the editorial pages of the New York Times.

The polar opinions expressed in the Times are instructive. Sadlowski attorney Joseph L. Rauh, Jr., who supported outsider contributions, reasoned that "without support from the publicfinancial contributors, volunteer workers, public-interest lawyersthe challenger to the union hierarchy would never have a chance." 17 Three weeks later, the Times editorialized in response: "Contributions from non-union sources raise a considerably greater threat, even one of corruption. . . . To encourage external contributions is to open the way to contributors seeking to buy something other than the well-being of a union or of the labor movement." 18

These two views form the horns of a dilemma that will reappear throughout this Comment.19 Ironically, despite the divergence of the views, both rely on an uncompromising reading of the LMRDA and its goal of "union democracy." 20 Proponents of

12 See, e.g., R. Stout, Money/Polmtics: A Report of the CtTtzens' Research Foundatxon CONFERENGE 8 (1974); Alexander, Rethinking Election Reform, 425 ANNALS 1, 2 (May 1976).

13 See J.D. Edelstexn \& M. Warner, Comparattve Union Democracy 329-33 (1975) [hereinafter cited as J.D. Edelstein]; J. Herling, Rrght to Charitenge: People and Power in the Steelworkers UnIoN (1972).

14 See J.D. EDELSTEN, supra note 13, at 319-28.

15 See James, supra note 5, at 348-49.

16 See, e.g., Raskin, Steel Union Election Is Awaited as Key Test in Organized Labor, N.Y. Times, Feb. 2, 1977, §D, at 7, col. 1; notes 119-22 infra.

17 Rauh, supra note 6.

18 Union Funds for Union Politics, N.Y. Times, Feb. 4, 1977, § A, at 22, col. 2. 19 See notes $43 \& 44,48,89,108-11$ infra \& accompanying text.

20 See notes 56-68 infra \& accompanying text. 
outsider support, citing congressional incantations of "union democracy" and "free and democratic" elections, claim that democracy is illusory unless rank-and-file challengers are accommodated in the political process. That, they say, requires outside money. Opponents of outsider support, citing the same congressional formulae, urge that democratic elections are not possible unless outside influence and tampering are avoided. Thus, merely parading behind a banner of "union democracy" will do nothing to resolve the stand-off.

A more profitable approach to the problem must begin with the realization that the term "democracy" is not self-defining. The legislators who enacted the LMRDA did not bother to explain the term; ${ }^{21}$ "democracy," after all, is a concept taught in grade school. Congress specifically rejected the New England town-meeting model of democracy, ${ }^{22}$ but it is not at all clear which of several remaining democratic models underlies the LMRDA. Did Congress intend to transplant traditional representative-democracy principles-in which one person from the rank and file is chosen to speak for an entire constituency-to the union setting? Was the intent of the legislature to supplant the autocratic nature of union politics with vigorous two-party competition? Or would Congress have been satisfied with the one-party politics-in which the democratic battles are fought at the "primary" stage-then existing in many regions of the country?

These questions may at first appear abstract, theoretical, or even philosophical. But they are highly relevant in determining how union elections should be structured and financed. A campaign between two members of the union hierarchy may well be considered democratic by traditional American standards, as would a campaign between two rank-and-file candidates or between an incumbent and a rank-and-file challenger. Despite the common label of democracy, however, the financial requirements of the candidates in each of the three campaigns would be quite divergent. Also, a political structure which legitimates opposition through the

21 The Senate report accompanying the IMRDA did state, however, that democracy required "the opportunity to infuence policy and leadership by free and periodic elections." Senate Labor CoMm. Rep., supra note 9, at 7, reprinted in [1959] U.S. Code Cong. \& AD. News 2318, 2323, also reprinted in I Legrs. Hist., supra note 9, at 403. See also Summers, The Public Interest in Union Democracy, $53 \mathrm{Nw}$. U. L. Rev. 610, 613 (1958).

22 Senate Labor Comm. Rep., supra note 9, at 7, reprinted in [1959] U.S. Code Cong. \& AD. NEws 2318, 2323, also reprinted in I LEcrs. Hist., supra note 9 , at 403 . 
creation of permanent parties ${ }^{23}$ will function much differently than a structure in which challengers emerge from the ranks with no formal, permanent power bases and with limited financial resources behind them. Yet both structures will be called "democracies." 24

This Comment examines the internal political structure of the American labor union and concludes that, as presently written and interpreted, the campaign financing provisions of the LMRDA are inadequate. They are designed for a two-party system which simply does not exist in a union setting. In part $I$, the Comment discusses Marshall v. Local 20, International Brotherhood of Teamsters, ${ }^{25}$ the first case to grapple with the outsider-funding issue. Part II explores the legislative history and underlying rationale of the LMRDA and proposes that the campaign financing provisions are rooted in two congressional objectives: eliminating corruption and fostering responsive leadership. In connection with the latter rationale, this part also describes the problems inherent in entrenched leadership and how the LMRDA election provisions attempt to cope with these problems. Part III focuses specifically on section $401(\mathrm{~g})$, the campaign financing provision. This part analyzes the judicial interpretations of section 401 (g) and suggests that the reason for the failures of the section is that the courts-and even the literal wording of section $40 \mathrm{l}(\mathrm{g})-$ neglect to take into account the gross disparities in strength and resources between incumbents and challengers. Finally, in part IV, an alternative reading of section $401(\mathrm{~g})$ is examined, and several new legislative approaches are proposed.

23 This type of structure has apparently been successful only once in the American labor movement. The International Typographical Union maintained an elaborate two-party system for many years. See S. LIPSET, M. TRow, \& J. ConEMAN, UNION DEMOCRACY (1956) [hereinafter cited as S. LIPSET].

Because the financing requirements of election campaigns are so dependent on the particular model of democracy involved, any decision on union campaign financing must await an analysis of the form of democracy in the union setting.

24 There are a number of excellent commentaries which explore the nature of union democracy. See J.D. EnELSTETn, supra note 13; C. KERR, UNIONS AND Union Leaders of Their OWN Choosing (1957); W. Leiserson, Amerucan Trade Union Democracy (1959); S. LIPSEx, supta note 23; P. TAFT, ThE Structure AND GovernMENT OF LABOR UNIONS (1954); Lipset, The Law and Trade Union Democracy, 47 VA. L. Rev. I (1961); Magrath, Democracy in Overalls: The Futile Quest for Union Democracy, 12 Indus. \& LAB. Rex. REv. 503 (1959); Stein, The Dilemma of Union Democracy, 350 AnNals 46 (Nov. 1963). For a discussion of union democracy in Europe, see A. Carew, Democracy and Government in European Trade Unions (1976); W. Galenson, Trade Umon Democracy in Western Europe (1961); J. Goldstein, The Government of Brttish Trade Unions (1952); J. Hughes, Trade Union Structure and Government (PT. 2) (1967); O. KAFN-FrEUND, LABOUR AND THE LAw (2d ed. 1977). For an early perspective, see S. WEBB \& B. WebB, Industrial Democracy (ed. 1920).

25 101 L.R.R.M. 2195 (N.D. Ohio), aff'd, 611 F.2d 645 (6th Cir. 1979). 


\section{Recent Case Law}

The first case to deal directly with the question of outsider campaign contributions in union elections was Marshall v. Local 20, International Brotherhood of Teamsters. ${ }^{26}$ In that case, the Secretary of Labor brought suit against the local, ${ }^{27}$ alleging that "moneys of an employer" were contributed to the campaign of the successful presidential candidate, Harold Leu, in violation of section $401(\mathrm{~g})$ of the LMRDA. Some of Leu's contributors were "employers" 28 in a technical sense-his doctor, for example, and other personal friends-although they certainly had no relationship with the union. ${ }^{29}$

The Secretary nonetheless contended that these contributions were improper. He cited Labor Department regulations which state that: "The prohibition against the use of employer money . . . is not restricted to employers who employ members of the labor organization in which the election is being conducted, or who have any business or contractual relationship with the labor organization." 30 The Secretary argued that section 401(g) has no limit. In his view, it applies to all employers, even those having no re-

26 Id.

27 The Secretary's suit was brought pursuant to his powers under $\$ 402$ of the LMRDA, 29 U.S.C. $\$ 482$ (1976). Section 402 (a) authorizes an individual union member who has exhausted his internal appeals to file a complaint with the Secretary of Labor alleging election irregularities. Id. $\$ 482(\mathrm{a})$. Section $402(\mathrm{~b})$ provides:

The Secretary shall investigate such complaint and, if he finds probable cause to believe that a violation of this subchapter [(title IV)] has occurred and has not been remedied, he shall, within sixty days after the filing of such complaint, bring a civil action against the labor organization as an entity in the district court .... to set aside the invalid election, if any, and to direct the conduct of an election or hearing and vote upon the removal of officers under the supervision of the Secretary . . . .

Id. $\$ 482(\mathrm{~b})$. See generally J. BELIACE, supra note 5, at 228-82; Note, The Enforcement Power of the Secretary of Labor Under Section 402 of the LMRDA, 1971 U. It.. L.F. 745.

28 "Employer" is defined as:

any employer or any group or association of employers engaged in an industry affecting commerce (1) which is, with respect to employees engaged in an industry affecting commerce, an employer within the meaning of any law of the United States relating to the employment of any employees or (2) which may deal with any labor organization concerning grievances, labor disputes, wages, rates of pay, hours of employment, or conditions of work, and includes any person acting directly or indirectly as an employer or as an agent of an employer in relation to an employee but does not include the United States or any corporation wholly owned by the Government of the United States or any State or political subdivision thereof.

LMRDA, $\$ 3(e), 29$ U.S.C. $\$ 402(e)(1976)$.

29 But see note 31 infra.

3029 C.F.R. $\$ 452.78$ (b) (1979). 
lationship with the union and no demonstrable interest in the outcome of the election. ${ }^{31}$

The defendant union challenged this broad construction of the term "employer." It claimed that the rationale behind section 401 (g)'s proscription of employer contributions was to prevent employers from unduly interfering with the internal structure of their own employees' unions. The union argued that a more sweeping ban on outside assistance would foreclose the opportunity of virtually any challenger to mount a successful campaign, and would undermine Congress's aim of encouraging free and democratic union elections.32 Thus, in the union's view, both the regulation and the Secretary's limitless application of section $401(\mathrm{~g})$ were invalid. ${ }^{33}$ The union also challenged the Secretary's construction of the statute on constitutional grounds, claiming that an interpretation that prohibited all disinterested-employer campaign contributions would violate potential contributors' first amendment rights. ${ }^{34}$

The district court rejected the union's analysis. The court held the regulation valid, and said that the regulation forbade the contributions from Leu's doctor and personal friends. ${ }^{35}$ The court was nonplussed by the union's arguments, and stated baldly that "an incumbent always has the advantage in an election." ${ }_{36}$ Emphasizing the spectre of corruption and influence-buying which would result from a more limited construction of the word "employer," the court intimated that-if it had its way-no outsider could contribute to a union election:

When the contest is not in the public arena, but in a private organization, the rules must clearly and definitely forbid outsiders from putting their weight on either side. When, as here, the contest is among members of labor, management of any kind has no business with it, and must

31 See 101 L.R.R.M. at 2196; Brief for Appellee at 10-18, Marshall v. Local 20, Int'l Bhd. of Teamsters, 611 F.2d 645 (6th Cir.), aff'g 101 L.R.R.M. 2195 (N.D. Ohio 1979) [hereinafter cited as Secretary's Brief].

The Secretary could have argued for the same result in Local 20 without interpreting "employer" so broadly because one contribution in fact came from an employer of members of Local 20. See Secretary's Brief, supra at 6. The relationship of other contributors to the union is unclear. See id. 6-7, 24-26.

32101 L.R.R.M. at 2197.

33 Id. The union need not have argued that the regulation was invalid; the regulation can be reconciled with a narrow interpretation of "employer." See note 186 infra and text accompanying notes 186-89 infra.

34611 F.2d at 652 .

35 Marshall v. Local 20, Int'l Bhd. of Teamsters, 101 L.R.R.M. 2195 (N.D. Ohio), affd, 611 F.2d 645 (6th Cir. 1979).

36 Id. 2197. 
be barred from getting involved either directly or indirectly. ${ }^{37}$

The Sixth Circuit affirmed.38 Judge Phillips, stressing the "clear" language of the provision, ${ }^{39}$ found support in the legislative history for his contention that: "The purpose of title IV of the Act [relating to elections] is to prevent the subjugation of the employees' representative's interests to those of management. Even the most subtle of influences can produce serious consequences for the loyalty and integrity with which the union should represent its membership." 40 The first amendment claim was also dismissed, based on the court's finding of a governmental interest in protecting union members from any undue influence exerted by outside contributors. ${ }^{41}$

It is not surprising that the Sixth Circuit and both the litigants in this case found solace in the underlying rationale of the LMRDA. Running like counterpoint throughout the Act are two distinct themes: ${ }^{42}$ one, an abhorrence of corruption and racketeering (cited by the Secretary of Labor and by the court); ${ }^{43}$ the other, a more positive insistence on individual rights and liberties (cited by the union). ${ }^{44}$ The two are related but are far from synonymous. To cite one without the other-as the court in Local 20 has done-is at best misleading. A more thorough analysis of the underlying rationale of the LMRDA is necessary to correctly resolve the issue.

37 Id. (emphasis added).

38611 F.2d 645. Judge Weick dissented, stating that failure to join the union's president as a defendant deprived him of due process. Id. 653-54.

39 Id. 651-52.

40 Id. 651.

41 Id. 652-53.

The issue of outsider contributions took on a new dimension in 1978 when the United Steelworkers of America adopted a rule prohibiting the receipt of any outside support in an election campaign. United Steelworkers Const. art. V, $\$ 27$ (1978). The rule was a direct by-product of the McBride-Sadlowski campaign of 1977, in which accusations of outside support were incessant. See notes 15-18 supra \& accompanying text and notes 119-22 infra. The rule was recently challenged in a lawsuit filed by loser Sadlowski. Sadlowski v. United Steelworkers, No. 79-2953 (D.D.C., filed Oct. 31, 1979). For a more complete discussion of the Steelworkers' rule, see Note, Restrictions on "Outsider" Participation in Union Politics, 55 CHI.KENT L. REv. 769 (1979).

Additionally, winner McBride sued some of Sadlowski's outside supporters, alleging that their contributions were in violation of $\$ 401(\mathrm{~g})$. The suit was dismissed on jurisdictional grounds. McBride v. Rockefeller Family Fund, 101 L.R.R.M. 2576 (S.D.N.Y.), affd, 612 F.2d 34 (2d Cir. 1979), cert. denied, 48 U.S.L.W. 3626 (U.S. March 31, 1980).

42 See text accompanying note 19 supra.

43 See 611 F.2d at 650-51; Secretary's Brief, supra note 31, at 14-16.

14 See, e.g., 101 I.R.R.M. at 2197. 


\section{The Dual Policies of the LMRDA}

The LMRDA was enacted in an atmosphere of heated and often divisive intensity. As Professor Cox noted in a frequently quoted ${ }^{45}$ caveat written shortly after the passage of the bill:

The legislation contains more than its share of problems for judicial interpretation because much of the bill was written on the floor of the Senate or House of Representatives and because many sections contain calculated ambiguities or political compromises essential to secure a majority. Consequently, in resolving them the courts would be well advised to seek out the underlying rationale without placing great emphasis upon close construction of the words. ${ }^{46}$

The "underlying rationale" to which Cox refers is welldocumented in the legislative history both preceding and contemporaneous with the passage of the Act. ${ }^{47}$ That legislative history makes

45 See, e.g., Hall v. Cole, 412 U.S. 1, 11 n.17 (1973); Wirtz v. Local 153, Glass Bottle Blowers Ass'n, 389 U.S. 463, 468 n.6 (1968); UAW v. National Right to Work Legal Defense \& Educ. Foundation, Inc., 590 F.2d 1139, 1148 (D.C. Cir. 1978); Brennan v. United Steelworkers, 554 F.2d 586, 593 (3d Cir. 1977); Usery v. Local 639, Int'l Bhd. of Teamsters, 543 F.2d 369, 387 n.50 (D.C. Cir. 1976), cert. denied, 429 U.S. 1123 (1977).

$46 \mathrm{Cox}$, supra note 4, at 852 (emphasis added). (Because of his participation in the drafting of the LMRDA, Professor Cox's remarks may carry greater authority than those of other commentators. See, e.g., 105 CoNc. REc. 5992 (1959) (remarks of Sen. J. Kennedy), reprinted in II LEGIS. Hist., supra note 9, at 1025; 105 ConG. REC. 6281 (1959) (remarks of Sen. Randolph), reprinted in II LEGIS. Hrst., supra note 9, at 1043.) Although Professor Cox's observations about the legislative history of the LMRDA apply most directly to titles I \& VII, see notes 150-70 infra \& accompanying text, the emphasized words are accurate guides to the entire Act, and have been used by the courts in interpreting both title IV and $\$ 401$. E.g., Wirtz v. Local 153, Glass Bottle Blowers Ass'n, 389 U.S. 463, 468 n.6 (1968); Brennan v. United Steelworkers, 554 F.2d 586, 593 (3d Cir. 1977); Usery v. Local 639, Int'l Bhd. of Teamsters, 543 F.2d 369, 387 n.50 (D.C. Cir. 1976), cert. denied, 429 U.S. 1123 (1977).

47 The complete contemporaneous legislative history is reprinted in I \& II Legis. HIST., supra note 9.

The Act was a specific response to the first interim report of the McClellan Committee, and both the Act and the accompanying reports incorporate prior bills and reports. See, e.g., SENATE LABOR CoMm. Rep., supra note 9, at 2, reprinted in [1959] U.S. CODE CoNG. \& AD. News 2318, 2318, also reprinted in I Legrs. Hrst., supra note 9 , at 398 ; H.R. ReP. No. 741 , 86th Cong., 1st Sess. 1-2, reprinted in [1959] U.S. CoDe Cong. \& AD. NEws 2424, 2424, also reprinted in I Lrgis. Hrst., supra note 9 , at $759,759-60$. Congress also responded to the Second Interim Report of the McClellan Committee. Id. 2, reprinted in [1959] U.S. Code Cons. \& AD. News 2424, 2424, also reprinted in I LeGis. Hrst., supra note 9, at 760; Levitan \& Loewenburg, The Politics and Provisions of the Landrum-Griffin Act [hereinafter cited as Levitan], in Regulating UNION Government 28, 54 (M. Estey, P. Taft \& M. Wagner eds. 1964). See generally J. BelLACE, supra note 5, at 1-8; Levitan, supra. See also Regulating UNION Government, supra; Sxmposium, supra note 1; Aaron, supra note 4 (pt. 1); Cox, supra note 4; note 2 supra and notes 49-54 \& 150-69 infra \& accompanying text. 
clear the two-pronged underlying rationale for the LMRDA: prevention of union corruption and assurance of responsive union leadership. ${ }^{48}$

The origins of both congressional policies can be traced to the three major sources of pressure for the enactment of the LMRDA. First, in 1958, the Senate Select Committee on Improper Activities in the Labor or Management Field (popularly known as the McClellan Committee) ${ }^{49}$ released its first report, ${ }^{50}$ a 462 -page collection of horror stories documenting, inter alia, dictatorial practices by union leadership, collusion with management, misuse of union funds, violence, and infiltration of some unions by "gangsters and hoodlums." 51 The Committee recommended federal legislation to curb the abuses uncovered during its hearings. ${ }^{52}$ Second, reformers also supported federal legislation as a means of improving the responsiveness of unions to their members. ${ }^{53}$ And third, management groups, eager to constrain growing union power through internal restraints, also pressed for ameliorative legislation. ${ }^{54}$ In September, 1959, the LMRDA was enacted. Its purpose was to protect employees and the general public from "breach of trust, corruption, disregard of the rights of individual employees, and other failures to observe high standards of responsibility and ethical conduct." 55

Thus, the congressional policies against corruption and in support of responsiveness have rather logical roots in the arguments pressed by the most avid supporters of federal legislation. And, as this Comment shall demonstrate, Congress viewed union democracy as the means to achieve both policies.

48 See text accompanying note 19 supra.

49 The Committee was chaired by Arkansas Senator John I. McClellan.

80 McCuellan CoMm. ReP., supta note 2.

51 Id. 4-7.

52 Id. 450-53.

53 Cox, supra note 4 , at 820 .

54 Id. 820-21; Levitan, supra note 47 , at 31-32.

55 LMRDA, $\$ 2$ (b), 29 U.S.C. $\$ 401$ (b) (1976).

The Act is divided into six major parts: a bill of rights for individual union members, LMRDA, title I, $\$ \$ 101-105,29$ U.S.C. $\$ \$ 411-415$ (1976); reporting and disclosure requirements for both unions and employers, LMRDA, title II, $\$ \S 201-211,29$ U.S.C. $\$ \$ 431-441$ (1976); trusteeships (the regulation of union control over its own subordinate locals), LMRDA, title III, $\$ \$ 301-306,29$ U.S.C. $\$ \$ 461-466$ (1976); union elections, LMRDA, title IV, $\$ \$ 401-403$, 29 U.S.C. $\$ \S 481-483$ (1976); safeguards for labor organizations, including the fiduciary responsibilities of union officers, LMRDA, title V, $\$ 501-504,29$ U.S.C. $\$ \S 501-504$ (1976); and miscellaneous provisions, LMRDA, title VI, $\$ 601-611,29$ U.S.C. $\$ \$ 521-531$ (1976). The final part of the Act, LMRDA, title VII, $\$ \$ 701-706$, amended various parts of the National Labor Relations Act, 29 U.S.C. $\$ \S 151-169$ (1976). 


\section{A. Democracy: The Solution to Union Corruption}

The McClellan Committee, after documenting labor misconduct and corruption, suggested that, given the opportunity to participate more actively in union affairs, the union members themselves could cleanse their organizations of corrupt and malevolent influences. ${ }^{56}$ One year later, the Senate report accompanying the proposed LMRDA noted: "Given the maintenance of minimum democratic safeguards and detailed essential information about the union, the individual members are fully competent to regulate union affairs." 57 The same report added that "[t]he ultimate responsibility rests upon individual union members to insure that their unions are efficiently and honestly run by taking a more active interest in the affairs of their organizations." 58

This emphasis on union self-regulation of corruption had political as well as practical origins. Not surprisingly, many union officials opposed the idea that the federal government could control the inner workings of their "private" organizations. 59 In addition, labor supporters feared that federal intervention could serve only to weaken the collective strength of unions and undermine their stand against management. ${ }^{60}$ To allay the suspicion that the LMRDA would reduce union effectiveness, Congress pointedly voiced its

56 MCCleldan CoMm. Rep, supta note 2, at 452.

57 Senate LABOR CoMm. Rep., supra note 9, at 7, reprinted in [1959] U.S. Code Cong. \& AD. News 2318, 2323, also reprinted in I Legrs. Hist., supra note 9 , at 403 .

58 Id. 12, reprinted in [1959] U.S. CODE CONG. \& AD. NEws 2318, 2329, also reprinted in I LEGIs. Hist., supra note 9, at 408.

59 See, e.g., Levitan, supra note 47, at 28, 39-40, 44; 105 CoNG. REc. 16,592 (1959) (letter of James B. Carey, President of the Int'l Union of Electrical, Radio, \& Mach. Workers, quoted by Rep. Cramer), reprinted in II LEGIs. Hist., supra note 9 , at 1709 .

60 This was a not unreasonable assumption, considering the support given the LMRDA by traditionally pro-management groups. See note 54 supra \& accompanying text.

Further, the attitude was not entirely self-serving-there was a strong argument that autocracy was better for the union rank and file. A number of commentators-likening labor unions to corporations, universities, churches, or even armies-note that private organizations are often autocratically rather than democratically run. Such commentators would argue that "too much political and civil liberty can weaken ... [a union], resulting in a thinner paycheck." Affeldt, The Labor Bill of Rights: A Bill of Protest, in SYMPOSIOM, supra note 1, at 175, 213. See also, e.g., M. Estey, The UnIONS 47, 54 (1967); C. KerR, supra note 24, at 10; G. Tyler, The Polttical IMperattve 281-85 (1968); Cox, supta note 4, at 829; Kahn-Freund, Trade Unions, The Law and Society, 33 Mon. L. Rev. 24I, 263 (1970). One union official even suggests that society approves of more autocratic union leadership-leadership sufficiently strong to "caution, restrain, admonish, and even punish" an unruly membership and keep the industrial peace. G. TYLER, supra, at 285 . 
support for a "strong independent labor movement" 61 and emphasized that government interference in internal union affairs would be minimal. Most of the "policing" which was required would be done by the union members themselves through traditional democratic mechanisms. ${ }^{62}$

\section{B. Democracy and Union Responsiveness}

\section{The Expectation of Representation}

Although the legislators who enacted the LMRDA saw democracy as a means of controlling the union corruption exposed by the McClellan Committee, "the sources of the statute lay much deeper than the committee's disclosure." 63 Democracy was favored in its own right, as an expression of individual freedom. ${ }^{64}$ Congress had, after all, bestowed upon the unions the right of exclusive representation; ${ }^{65}$ the individual worker, by virtue of the collective bargaining process, had lost his right to contract independently with his employer. ${ }^{66}$ The least he could expect in exchange for this concession was a voice in the internal affairs of his union. The Senate Committee on Labor and Public Welfare was fully aware of the federal government's obligation:

Under the National Labor Relations and Railway Labor Acts the union which is the bargaining representative has power, in conjunction with the employer, to fix a man's wages, hours, and conditions of employment. The individual employee may not lawfully negotiate with his employer. He is bound by the union contract. In practice, the union also has a significant role in enforcing the grievance procedure where a man's contract rights are enforced. The Government which gives unions this power has an obligation to insure that the officials who wield it are responsive to the desires of the men and women whom they

61 SENATE Labor CoMm. REP., supra note 9, at 5, reprinted in [1959] U.S. Code Cong. \& AD. News 2318, 2322, also reprinted in I Legrs. Hrst., supra note 9 , at 401.

62 See text accompanying notes $57 \& 58$ supra.

63 Summers, American Legislation for Union Democracy, 25 MoD. L. Rev. 273, 274 (1962).

64 Those who favor union democracy often view unions as mini-governments analogous to the United States government and formulated from the same principles. See, e.g., Griffin, A New Era in Labor-Management Relations, in Sxmposium, supra note 1, at 25, 26; notes 21-24 supra \& accompanying text. But see, e.g., Summers, supra note 63, at 278.

65 See National Labor Relations Act, $\S 9(a), 29$ U.S.C. §159(a) (1976).

66 Id. 
represent. The best assurance which can be given is a legal guaranty of free and periodic elections. ${ }^{67}$

The mandate is clear: union officers must not only be honest; they must be responsive to the needs of their constituency. ${ }^{68}$ And that, thought Congress, was unlikely so long as entrenched, autocratic incumbents remained unchallenged from within.

\section{The Perils of Incumbency}

In the late 1950s, "one-man dictatorships" 69 were thriving within labor unions. ${ }^{70}$ Indeed, unions had proven themselves to be particularly susceptible to autocracy. ${ }^{71}$ Opposition to the union hierarchy simply was not acknowledged as a legitimate form of intraunion activity. ${ }^{72}$ The two-party system was rare ${ }^{73}$ and, even if periodic elections were mandated by the union constitution, there was no limit to the number of terms an officer could serve. ${ }^{74}$ This factor alone had serious consequences:

[B]eyond a certain point, length of service in a leadership position tends to become self-perpetuating, whether in a union, business organization, or political position. The cult of personality becomes increasingly evident, and, as time goes on, criticism of union policy tends to be regarded

67 Senate LABOR CoMM. ReP., supta note 9, at 20 (emphasis added), reprinted in [1959] U.S. CoDe CoNG. \& AD. NEwS 2318, 2336, also reprinted in I LEGIS. Hrst., supra note 9 , at 416.

$68 \mathrm{Mr}$. Justice Brennan, writing for the Supreme Court in Wirtz v. Hotel Employees Local 6, 391 U.S. 492, 503 (1968), noted pointedly that "benevolent as well as malevolent entrenched leaderships" were subject to the strictures of the LMRDA; the mere fact that the entrenched incumbent was "enlightened" was irrelevant. Accord, Local 3489, United Steelworkers v. Usery, 429 U.S. 305, 309, 311-12 (1977).

69 MGCreltan CoMm. Rep., supra note 2, at 4.

70 See generally, e.g., J. BARBASH, AMERICAN UNIONS 93-96 (1967); M. EsTex, supra note 60, at 53-56; see also J. Hutchinson, supra note 2; R. KENNEDy, supra note 2; J. McCleLt.AN, supra note 2.

71 See C. KerR, supra note 24, at 10, 12; S. LIPSET, supra note 23, at 4-13; R. Mrchels, Poltricat Parties 93-201 (Dover ed. 1959).

The autocratic nature of many unions should not be surprising. The unionespecially at the local levels-is relatively homogeneous in composition and unidimensional in purpose: "The sociologic base is not present for a political pluralism. Hence, a union official, once elected, can be re-elected without major opposition for decades." G. TYLER, supra note 60, at 284.

72 See M. EsTEY, supra note 60, at 50; S. LIPSET, supra note 23, at 270-305; James, supra note 5, at 250-51, 265; Lipset, supra note 24, at 40-43. See also note 205 infra \& accompanying text.

73 See note 23 supra; Kahn-Freund, supra note 60, at 263-64.

74 Of 111 national union constitutions studied by the Department of Labor in 1958, not one limited the number of terms which could be served. U.S. BurEav of Labor Statistics, Dep't of Labor, Bul.. No. 1239, Union Constrtution Provisions: Electron and Tenure of National and International Union OfFICERS 21 (1958), cited in M. Estey, supta note 60, at 53. 
as criticism of the individual leaders and comes perilously close to disloyalty, as well as organizationally risky for the critic. ${ }^{75}$

Finally, incumbents remained in power not only because of the inherent advantages of incumbency, ${ }^{76}$ but also because they controlled the electoral machinery. ${ }^{77}$ It is difficult to imagine a system more inimicable to union democracy.

More than any other part of the LMRDA, title IV 78 (the election provisions) reflects a congressional determination to thwart the all-powerful entrenched incumbents and to encourage responsive leadership. ${ }^{79}$ Thus, section 401 (a) ${ }^{80}$ requires the union to elect its officers at five-year intervals in order "to compel rotation in office thereby enabling the membership to get rid of an undesirable incumbent officer and replace him with one whom they prefer." 81 Section $401(c){ }^{82}$ provides every bona fide candidate with equal access to the union membership lists for the distribution of campaign materials and guarantees equal treatment of candidates in other areas as well, thereby "correct[ing] the conditions, so prevalent in

75 M. Estex, supra note 60, at 53 (footnote omitted). See also note 205 infra \& accompanying text.

76 Such advantages include frequent opportunity to contact members, control of the union newspaper, access to union counsel, and creation of an administrative bureaucracy giving incumbents both significant patronage power and an active campaign staff. See generally James, supra note 5, at 270-81; Summers, supra note 63, at 293; Note, Union Elections and the LMRDA: Thirteen Years of Use and Abuse, 81 Y ALE L.J. 407, 460-68 (1972) [hereinafter cited as Thirteen Years of Use].

77 See Summers, Judicial Regulation of Union Elections, 70 YALE L.J. 1221, 1228-29 (I961).

78 LMRDA, $\$ \$ 401-403$, 29 U.S.C. $\$ \$ 481-483$ (1976).

79 Senator Barry Goldwater of Arizona criticized the original Kennedy-Ervin bill because,

as introduced, [it] contained no provisions guaranteeing equal treatment of bona fide candidates for union office, thus leaving every advantage in the hands of the incumbent union officers. Thus, it would have done nothing to correct the conditions, so prevalent in many unions, which permit the incumbent officers to perpetuate themselves in office indefinitely.

105 CoNG. Rec. 19,764 (1959) (remarks of Sen. Goldwater), reprinted in II LEGIS. Hist., supra note 9 , at 1843,1850 , also reprinted in Goldwater, The Legislative History and Purposes of LMRDA, in SYMPOSIOM ON LMRDA 32, 51 (R. Slovenko ed. 1961) [hereinafter cited as Goldwater, Legislative History]. To help change these conditions, the bill was amended to include a provision giving all candidates the opportunity to use "membership lists for transmitting campaign literature as well as the requirement permitting all candidates to have observers at both the casting and counting of the ballots." Id. (These requirements are contained in $\$ 401$ (c) of the LMRDA, 29 U.S.C. $\$ 481$ (c) (1976).)

80 LMRDA, \$ 401(a), 29 U.S.C. $\$ 481$ (a) (1976).

81105 Cong. Rec. 19,763 (1959) (remarks of Sen. Goldwater), reprinted in II LEGIS. Hist., supra note 9 , at 1843, 1849, also reprinted in Goldwater, Legislative History, supra note 79 , at 50 .

82 LMRDA, $\$ 401(\mathrm{c}), 29$ U.S.C. $\$ 481$ (c) (1976). 
many unions, which permit the incumbent officers to perpetuate themselves in office indefinitely." ${ }^{83}$ Section 401 (e) ${ }^{84}$ establishes the right of any union member to run for and hold office, subject to reasonable qualifications uniformly imposed. This provision was designed to ensure a candidate pool large enough to take on the entrenched incumbency. 85

Section 401 (g) ${ }^{86}$ goes further. Like its companion provisions, it was designed to equalize the inherently imbalanced campaign of the typical union election. By cutting off two of the most lucrative sources of incumbent funding-the union coffers themselves and, to a lesser extent, the pocketbook of a collusive employer-the provision attempts to temper the vast strength of the incumbent. At the same time, it protects the rank and file from illicit use of their dues payments ${ }^{87}$ and from the corrupting influence of a meddling employer..$^{88}$

Thus, the provision represents the coalescence of the two themes which pervade the LMRDA: policing corruption and ensuring responsive leadership. ${ }^{89}$ In their interpretation of section $401(\mathrm{~g})$, the courts have forgotten that both these objectives must be satisfied. This Comment concludes that though section $401(\mathrm{~g})$, as presently interpreted, may succeed in deterring corruption, it has not helped to loosen the grip of the incumbent over the electoral process. ${ }^{90}$ Indeed, some commentators have suggested that section $401(\mathrm{~g})$ may actually serve to hinder the challenger more than it restricts the incumbent.91

83105 CoNG. REC. 19,764 (1959) (remarks of Sen. Goldwater), reprinted in II LEGS. HIST., supra note 9, at 1843, 1850, also reprinted in Goldwater, Legislative History, supra note 79 , at 51 .

${ }^{84}$ LMRDA, $\$ 401$ (e), 29 U.S.C. $\$ 481$ (e) (1976).

85 See, e.g., Wirtz v. Hotel Employees Local 6, 391 U.S. 492,499 (1968) (limiting candidates to prior holders of elective office unreasonable). Accord, Local 3489, United Steelworkers v. Usery, 429 U.S. 305, 312 (1977) (provision limiting eligibility for office to members who attended at least one-half local's meetings for three years preceding the election unreasonable).

86 LMRDA, $\$ 401$ (g), 29 U.S.C. $\$ 481$ (g) (1976).

87 See, e.g., Retail Clerks Local 648 v. Retail Clerks Int'l Ass'n, 299 F. Supp. 1012, 1023 (D.D.C. 1969).

88 See, e.g., Hodgson v. Liquor Salesmen Local 2, 334 F. Supp. 1369, 1380 (S.D.N.Y.), affd, 444 F.2d 1344 (2d Cir. 1971).

89 See text accompanying note 19 supra.

90 In a recent survey conducted to determine the impact of the LMRDA, over 60\% of the union members questioned felt that the LMRDA had not affected their ability to become a union officer. D. McLaughLIN, supra note 5, at 61 . The survey also demonstrated that opposition slates are more frequent today than they were prior to 1959 , but that "in the main, the incumbents still continue to win the large majority of the elections, as they always have." Id. 9-10.

$91[T]$ he government prohibition against expending union funds in support of candidates ... seems to hamper the opposition more than the incumbent 


\section{SECTION 401(g) OF THE LMRDA}

\section{A. Judicial Interpretations}

Until the decision in Marshall $v$. Local 20, International Brotherhood of Teamsters ${ }^{22}$ in 1979 , it could be said with certainty that the courts were using section $401(\mathrm{~g})$ for its intended effect-constraining the power of incumbent candidates. ${ }^{93}$ Most courts were relentless in their application of section $401(\mathrm{~g})$ to strike down the use of union funds or facilities to promote the candidacy of the incumbent. ${ }^{94}$ In Hodgson v. Liquor Salesmen Local

administration, which has the national machinery at its disposal. . . . In the absence of adequate established channels, the autonomy of locals or other subdivisions to disburse funds for campaign purposes (perhaps up to a certain limit) may be a lesser evil.

J.D. EDErstein, supra note 13, at 333. See J. BELIACE, supra note 5, at 189 ("[T]he practical effect of a ban on outside support is the strengthening of the campaign position of the incumbents."); notes 134-35 infra \& accompanying text. 92101 L.R.R.M. 2195 (N.D. Ohio), aff'd, 611 F.2d 645 (6th Cir. 1979).

93 See, e.g., Retail Clerks Local 648 v. Retail Clerks Int'l Ass'n, 299 F. Supp. 1012, 1023 (D.D.C. 1969).

94 See, e.g., Usery v. Stove Workers Int'I Union, 547 F.2d 1043 (8th Cir. 1977); Usery v. International Org. of Masters, 538 F.2d 946 (2d Cir. 1976); Hodgson v. Liquor Salesmen Local 2, 444 F.2d 1344 (2d Cir. 1971); Shultz v. Local 6799, United Steelworkers, 426 F.2d 969 (9th Cir. 1970), aff'd on other grounds sub nom. Hodgson v. Local 6799, United Steelworkers, 403 U.S. 333 (1971); Brennan v. Local 300, Laborers Int'l Union, 85 L.R.R.M. 2648 (C.D. Cal. 1974); Brennan v. Sindicato Empleados de Equipo Pesado, 370 F. Supp. 872 (D.P.R. 1974); Hodgson v. UMW, 344 F. Supp. 17 (M.D. Fla. 1972).

Occasionally, claimed union contributions have withstood challenge under $\$ 401(\mathrm{~g})$. See, e.g., New Watch-Dog Comm. v. New York City Taxi Drivers Local 3036, 438 F. Supp. 1242, 1252 (S.D.N.Y. 1977) (single questionable issue of union newspaper failed to establish substantial past violation or likelihood of repetition needed for issuing preliminary injunction); Cefalo v. District 50, UMW, 311 F. Supp. 946, 954-55 (D.D.C. 1970) (claim that incumbent arranged trips by union officials to promote his candidacy dismissed for insufficent evidence); Shultz v. Local 1299, United Steelworkers, 324 F. Supp. 750, 758 (E.D. Mich. 1970), aff'd in part on other grounds and rev'd in part on other grounds sub nom. Hodgson v. Local 1299, United Steelworkers, 453 F.2d 565 (6th Cir. 1971) (despite "serious reservations" about incumbents' use of union newspaper, single publication "did not amount to "propoganda organ" "advancing candidacy of incumbents).

Other than Local 20, the few attempts to raise the issue of employer funding of incumbents have been unsuccessful. See, e.g., McBride v. Rockefeller Family Fund, 612 F.2d 34 (2d Cir. 1979), cert. denied, 48 U.S.L.W. 3626 (U.S. March 31,1980 ) (no private right of action against employers allegedly violating $\$ 401(\mathrm{~g})$ ); Usery v. Local 639, Int'l Bhd. of Teamsters, 543 F.2d 369, 381 (D.C. Cir. 1976), cert. denied, 429 U.S. 1123 (1977) (although employer assistance to incumbents "was undoubtedly violative of Title IV," Secretary of Labor rationally concluded it did not affect outcome of election); Hodgson v. Liquor Salesmen Local 2, 334 F. Supp. 1369, 1378-79 (S.D.N.Y.), aff'd, 444 F.2d 1344 (2d Cir. 1971) (statements made by employer on election day did not promote incumbents' candidacy).

A complete synopsis of $\$ 401(\mathrm{~g})$ complaints and litigation can be found in annual reports on the LMRDA by the Labor-Management Services Administration. E.g., U.S. Labor-Management Services Administration, Dep't of Labor, Complitance, ENforcement and Reporting in 1975 (1975). See also U.S. OfFTcE of

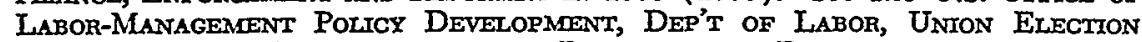
Cases UNDer the Labor-Management Reporting and Disclosure Act 1966-1970 (1972). 
2,95 for example, the Secretary of Labor sued the union, alleging that union moneys had been spent to promote the candidacy of the incumbent, who had won by a narrow margin. The court of appeals affirmed the district court and held that the union expense of over $\$ 2,000$ violated section $401(\mathrm{~g})$, "which is absolute and unequivocal in its prohibition against the use of any Union funds for such a purpose." 96

The court in Shultz $v$. Local 6799, United Steelworkers ${ }^{97}$ favored an even more exacting approach. In holding that the International's expenditure of $\$ 13.04$ to promote the campaign of one candidate was a violation of section $401(\mathrm{~g})$, the court insisted that the provision must be taken at face value:

The legislative history of the Act does not indicate that Congress intended to place a limit on the amount that a union might lawfully spend to aid a candidate for office or that it meant to encourage troublesome factual disputes over how much (or little) money constitutes a "de minimus" amount; and the language of the provision itself is clear and unambiguous. It provides in terms that "no moneys" of a union shall be spent to promote the candidacy of any person for union office..$^{98}$

In dicta, the court went even further. Acknowledging "that the object of the section is to prohibit discrimination between candidates," 99 the court nonetheless insisted that even if the union were to contribute equally to all candidates, a violation of section 401 (g) would be found. ${ }^{100}$ The court reasoned that because the statute does delineate lawful-as well as unlawful-union expenditures, ${ }^{101}$ the failure of Congress to list "equal" campaign contributions as a lawful activity must make such contributions unlawful. ${ }^{102}$

95344 F. Supp. 1369 (S.D.N.Y.), aff'd, 444 F.2d 1344 (2d Cir. 1971).

96444 F.2d at 1350.

97426 F.2d 969 (9th Cir. 1970), aff'd on other grounds sub nom. Hodgson v. Local 6799, United Steelworkers, 403 U.S. 333 (1971).

98 Id. 972.

99 Id.

100 Id. See Camarata v. International Bhd. of Teamsters, 102 L.R.R.M. 3053, 3061 (D.D.C. Sept. 24, 1979) (enjoining union to include insurgents' literature in union newspaper on the basis of equal space and prominence would violate $\S 401(\mathrm{~g})$ and first amendment).

101 The last sentence of $\$ 401(\mathrm{~g})$ reads: "Such moneys of a labor organization may be utilized for notices, factual statements of issues not involving candidates, and other expenses necessary for the holding of an election." LMRDA, $\S 401(\mathrm{~g})$, 29 U.S.C. $\$ 481(\mathrm{~g})(1976)$.

102426 F.2d at 972. But see Yablonski v. UMW, 305 F. Supp. 876, 877 (D.D.C. 1969) (supplementing 305 F. Supp. 868 (D.D.C. 1969)) (union could 
Judicial insistence on strict application of section $401(\mathrm{~g})$ has not been limited to cases of abuse by incumbents. The provision has been applied to limit the challenger as well. For example, in Loekle v. Swayduck, ${ }^{103}$ the plaintiff, a union member for over 20 years, decided to challenge the long-entrenched leadership. $\mathrm{He}$ wanted to give a campaign speech at a shop meeting, and sued the union, asking the court to enjoin the enforcement of union rules forbidding such campaigning. ${ }^{104}$ Because campaign speeches by incumbents at union halls had previously been held to violate section $401(\mathrm{~g}),{ }^{105}$ the court refused to enjoin enforcement of the rules, noting that "[a]lthough $\S 401$ (g) of the Act was originally enacted in light of evidence incumbents had used union funds to promote their candidacy, the language makes it clear that this prohibition is also applicable to non-incumbents." ${ }^{106}$ In Marshall $v$. Local 20, International Brotherhood of Teamsters, the Sixth Circuit used similar logic to strike down the challenger's use of employer moneys, citing Shultz $v$. Local 6799, United Steelworkers to justify its rationale..$^{107}$

The courts' strict construction of section 401 (g) was proper when the target of their opprobrium was the incumbent. Such an approach to incumbent funding did not conflict with the dual legislative purpose of the provision-deterring corruption and promoting union democracy. ${ }^{108}$ Further, a broad formulation dispensed with the subtleties of line drawing and appeared easy to administer. ${ }^{109}$

The problems inherent in section $401(\mathrm{~g})$ began to emerge only when the provision was applied to the challenger in a union election. Suddenly, it seemed impossible to satisfy one purpose under-

devote space in its newspaper to views of candidates, so long as the airing of views was on a nondiscriminatory basis); Jenkins, Trade Union Elections in REgulating UnIoN Government 54, 172 (M. Estey, P. Taft \& M. Wagner eds. 1964) (although equal space devoted to candidate views is technically use of union funds, there is no violation of $\S 401(\mathrm{~g})\rangle$; note 201 infra. See generally $\mathrm{J}$. BeLLACE, supra note 5 , at 185-87; Summers, supra note 63, at 294.

10394 L.R.R.M. 2442 (S.D.N.Y. 1976).

104 Id. 2448.

105 Id. 2448-49 (citing Brennan v. Sindicato Empleados de Equipo Pesado, 370 F. Supp. 872,879 (D.P.R. 1974)).

10694 L.R.R.M. at 2449.

107611 F.2d at $651-52$ (citing 426 F.2d at 972).

108 See text accompanying note 19 supra.

109 See Local 20, 101 L.R.R.M. at 2197; Secretary's Brief, supra note 31, at 16-17. 
lying the section without sacrificing the other. ${ }^{110}$ As this Comment will demonstrate, this dilemma is rooted in the statute itself. Section $401(\mathrm{~g})$ is simply not designed well.111 But the courts-faced with a poorly conceived provision-have only exacerbated the problem. Convinced that corruption is the main evil to be addressed by the provision, the courts have invariably concluded that section 401 (g) applies equally to both challengers and incumbents. In so doing, they have pushed aside the other critical function of the section: to ensure responsive union leadership by encouraging effective challenges to the entrenched incumbents.

\section{B. Why Has Section 401 (g) Failed?}

The anomalous result described above is possible because the legislators who drafted section 401(g)-and the courts which have interpreted it-have failed to account for the electoral power of the union staff. Unions, after all, are vast bureaucracies, ${ }^{112}$ often employing hundreds ${ }^{113}$ of paid workers simply to oil and run the union machinery. These staff members, often dependent on the incumbent administration for their jobs, ${ }^{114}$ willingly provide the incumbent with free public relations, ${ }^{115}$ legal advice, ${ }^{116}$ and other services. ${ }^{117}$ Their mere presence among the rank and file "provides a network of free and well distributed campaigners." 118 And, of course, they contribute money. In the 1977 Steelworkers election, for example, Lloyd McBride, the administration-backed candidate, received a reported $\$ 182,000$ in contributions ${ }^{119}$ while insurgent

110 Judge Phillip's opinion in Marshall v. Local 20, Int'l Bhd. of Teamsters focused solely on congressional concern with corruption and influence-buying. It failed to mention, even in passing, the second congressional policy in favor of responsiveness of union officials.

111 See notes 134-46 infra \& accompanying text.

112 For an extreme example, see J. BARBASH, supra note 70 , at 88 (listing 51 staff departments of the United Auto Workers Union).

113 See, e.g., James, supra note 5, at 277.

114 See generally J. BARBASH, supra note 70, at 99 ("Dismissal was the likely price of neutrality or of aiding the unsuccessful candidate-a situation which has not been changed by LMRDA."); James, supra note 5, at 277 .

115 James, supra note 5, at 277.

116 Id. $280-81$.

117 Id. 277.

118 Id.

119 Ignatius, USW's McBride to Offer Analysis of Gift Data Today, Wall St. J., Jan. 21, 1977, at 10, col. 5 .

The 1969 Mineworkers election reflected a similar pattern. The incumbents' re-election campaign was financed in part through contributions to the Miners' Committee for Boyle, Titler, Owens (the incumbent slate). The Committee received $\$ 142,710$ from 229 persons, "virtually all of whom were on the union payroll;" Hodgson v. UMW, 344 F. Supp. 17, 24 (D.D.C. 1972). 
Edward Sadlowski collected $\$ 153,000 .^{120}$ The significant distinction between the two candidates' campaign finances, however, was in the percentage of contributions from union staffers. At least eighty-six percent of McBride's contributions came from paid union staffers, ${ }^{121}$ while more than half of Sadlowski's support came from outside the union. ${ }^{122}$

The power which the incumbent can wield over his staffers has been graphically illustrated in the case law. In Hodgson $\boldsymbol{\nu}$. $U M W,{ }^{123}$ the Secretary of Labor brought suit alleging violations of section $401(\mathrm{~g})^{124}$ in the 1969 Mineworkers election between W.A. "Tony" Boyle and Joseph A. Yablonski.125 The court found that the union administration had "timed and manipulated" staff salary increases to coincide with the election "in an effort to attract the support of its employees for the incumbent officers in terms of services and financial aid." 126 Outright coercion was applied as well. One temporary union staffer testified that the district president, his employer, "made it clear that his continued status on the District's payroll was contingent upon his willingness to contribute his so-called fair share of $\$ 175 . " 127$

A similar story was recounted in Brennan $\%$. United Steelworkers. ${ }^{128}$ In that case, Steelworkers Union president I.W. Abel is quoted as admitting that he "assume[d]" that district directors and their staff would contribute up to $\$ 500$ each to support the administration-backed candidate in an election for district director. ${ }^{129}$ Judge Van Dusen noted: "The facts of this case illustrate graph-

120 Ignatius, supra note 119.

121 Id.

122 Id. One source reported that only 5.4\% of Sadlowski's support came from the union rank and file. Wall St. J., Jan. 24, 1977, at 12, col. 2. See generally James, supra note 5, at 348-49.

123344 F. Supp. 17 (D.D.C. 1972).

124 See note 27 supra.

125 Boyle won with 80,577 votes to 46,076 for Yablonski; less than a month later Yablonski and his family were murdered at Boyle's direction. See generally United Mine Workers' Election: Hearings Before the Subcomm. on Labor of the Senaie Comm. on Labor \& Public Welfare, 91st Cong., $2 d$ Sess. (pt. 1), \& 92d Cong., 1st Sess. (pt. 2) (1970-71); J. Finlex, The Corrupt Kingrom 255-79 (1972); Rauh, LMRDA-Enforce It or Repeal It, 5 GA. L. REv. 643 (1971); Fair Election Procedures Under the Labor-Management Reporting and Disclosure Act of 1959 and the United Mine Workers, 6 CouUM. J.L. \& Soc. Prob. 76 (1971). 126344 F. Supp. at 25.

$127 \mathrm{Id}$. Furthermore, the president "conceded that he expected all paid employees in his District to contribtute . . . and that he had made them aware of his expectations." Id.

128554 F.2d 586 (3d Cir. 1977).

$129 \mathrm{Id} .602 \mathrm{n} .9 \mathrm{a}$; see id. $603 \mathrm{n} .9 \mathrm{~b}$ (official fundraising arm of the Steelworkers sought $\$ 500$ per director and $\$ 50$ per staff member for district director's campaign). 
ically the abuses of power which the LMRDA was enacted to prevent. The Union hierarchy, rather than remaining neutral and maintaining the integrity of the electoral process, closed ranks around its own candidate to prevent an independent contender from gaining a foothold." 130

The most blatant forms of staff coercion, of course, are easily snared by section $401(\mathrm{~g}) .{ }^{131}$ But even a campaign contribution made free of explicit pressure can be tainted by more subtle influences, real or perceived. The Supreme Court recognized this problem in the public arena almost a century ago when it ruled in Ex parte Curtis ${ }^{132}$ that a precursor of the Hatch Act was not unconstitutional:

If contributions from those in public employment may be solicited by others in official authority, it is easy to see that what begins as a request may end as a demand . . . . Contributions secured under such circumstances will quite as likely be made to avoid the consequences of the personal displeasure of a superior, as to promote the political views of the contributor,-to avoid a discharge from service, not to exercise a political privilege. ${ }^{133}$

As presently interpreted, the LMRDA makes no allowance for this inevitable-and dangerous-result. ${ }^{134}$ Thus, section 401(g) now actually works to help the incumbent candidate by shutting off access to union and employer funds for all candidates. This construction denies financial aid to the rank-and-file challenger while

130 Id. 608.

131 See, e.g., notes 126 \& 127 supra \& accompanying text.

132106 U.S. 371 (1882).

${ }^{133}$ Id. 374. See United States Civil Serv. Comm'n v. National Ass'n of Letter Carriers, 413 U.S. 548, 566-67 (1973) (prohibition of political activity needed to prevent coercion by superiors); United Pub. Workers v. Mitchell, 330 U.S. 75, 96-99 (1947) (prohibition of political activity promotes efficiency in public service by preventing promotion of personnel as a result of political, rather than official effort); United States v. Wurzbach, 280 U.S. 396, 398-99 (1930) (prohibition of contributions from public service employees to congressmen is constitutional).

134 The Department of Labor's regulations provide:

Unless restricted by constitutional provisions to the contrary, union officers and employes [sic] retain their rights as members to participate in the affairs of the union, including campaigning activities on behalf of either faction in an election. However, such campaigning must not involve the expenditure of funds in violation of section $401(\mathrm{~g})$. Accordingly, officers and employees may not campaign on time that is paid for by the union, nor use union funds, facilities, equipment, stationery, etc., to assist them in such campaigning. Campaigning incidental to regular union business would not be a violation.

29 C.F.R. $\$ 452.76$ (1979) (emphasis added). 
leaving the union staffers free to contribute large sums to their employer, the incumbent. ${ }^{135}$

This approach might not have deleterious consequences in a strong two-party system where supporters would funnel their contributions through organized party channels. Candidates-elite members of their respective parties ${ }^{136}$-would enter the campaign with a strong power base and significant financial support. ${ }^{137}$ The natural advantages of incumbency ${ }^{138}$ would remain, of course, but would be tempered by the presence of a permanent, organized opposition party. ${ }^{139}$ This structure, very similar to that of American public government, ${ }^{140}$ may have been the democratic model which Congress envisioned when it enacted the LMRDA. ${ }^{141}$

Union politics, however, has rarely been structured along twoparty lines. ${ }^{142}$ In most unions, the incumbent or administrationbacked candidate will run unopposed or face a challenger with few resources at his disposal.143 In such a structure, the claim that "an incumbent always has the advantage in an election" 144 is a monumental understatement. The incumbent has more than "the advantage"; he holds the ticket to self-perpetuating autocracy. Unless the campaign financing provisions of the LMRDA are construedor rewritten ${ }^{145}$-with full cognizance of this imbalance, the objectives of the statute will continue to be thwarted.146

135 See note 91 supra \& accompanying text.

136 See C.W. MLls, The Power EltTe (1956).

137 In addition, these candidates would have well-honed administrative and

leadership skills. See S. LIPSET, supra note 23, at 260-64.

138 See note 76 supra.

139 See S. LIPSET, supra note 23 , at 276-77. Cf. note 73 supra \& accompanying text (two-party system is rare in unions).

140 For a classic study of the structure of American government, see A. DE

Tocqueviule, Democracy in America. (P. Bradley ed. 1945).

141 See notes 21-24 supra \& accompanying text.

142 See note 23 supra; Kahn-Freund, supra note 60, at 263-64.

143 See, e.g., M. Estex, supra note 60 , at 50.

144 Marshall v. Local 20, Int'l Bhd. of Teamsters, 101 L.R.R.M. 2195, 2197

(N.D. Ohio), aff'd, 611 F.2d 645 (6th Cir. 1979).

145 See also Note, The Election Labyrinth: An Inquiry Into Title IV of the

LMRDA, 43 N.Y.U. L. REv. 336, 348-50 (1968) [hereinafter cited as The Election

Labyrinth]. That Note concludes:

Because of the uncertain relationship between $[\$ \$ 501(\mathrm{a}), 503(\mathrm{a})$, and $401(\mathrm{~g})] \ldots$ and the attendant opportunities for circumvention, it it [sic] doubtful that these provisions have effectively precluded use of union funds to promote the candidacy of incumbent leaders. In recognition of the reality that campaigns cost money it would, perhaps, be better to draft a single coherent scheme which would restrict, without purporting Id. 350 .

to prohibit, use of union funds and facilities for these purposes.

146 It should also be noted that the discriminatory effect of $\$ 401(\mathrm{~g})$ may open the provision to attack on equal protection grounds. Although it is beyond the 


\section{Equalizing Incumbent and Challenger: The Alternatives}

\section{A. Reinterpreting Section $401(\mathrm{~g})$}

The defendant union in Marshall v. Local 20, International Brotherhood of Teamsters ${ }^{\mathbf{1 4 7}}$ was well aware of the fact that a broad interpretation of the phrase "moneys of an employer" would, in effect, incapacitate non-elite challengers who, unlike their incumbent opponents, could turn nowhere else for necessary monetary support. Thus, the union, under the control of the victorious challenger, argued that "employer" should be more narrowly construed to encompass only "interested employers"-such as those employers with a direct bargaining or vending relationship with the union. ${ }^{148}$

In support of its contention, the union referred the court to section 101(a)(4) of the LMRDA, ${ }^{149}$ which prohibits an "interested employer or employer association" from financing, encouraging, or

scope of this Comment to engage in extensive equal protection analysis, a brief discussion would be appropriate. In Buckley v. Valeo, 424 U.S. 1 (1976), the landmark case which explored the constitutionality of the Federal Election Campaign Act of 1971, 2 U.S.C. $\$ \$ 431-456$ (1976), the Court upheld the constitutionality of contribution limitations in the public forum. The Court rejected the contention that these limitations "work such an invidious discrimination between incumbents and challengers that the statutory provisions must be declared unconstitutional on their face." Id. 30-31. It did, however, leave open the possibility that invidious discrimination against the challenger could be found under other circumstances. In a lengthy footnote, the Court cautioned that contribution limitations, coupled with expenditure limitations, might "invidiously discriminate against major-party challengers and minor-party candidates." Id. 31 n.33. The Court continued:

Since an incumbent is subject to these limitations to the same degree as his opponent, the Act, on its face, appears to be evenhanded. The appearance of fairness, however, may not reflect political reality. Although some incumbents are defeated in every congressional election, it is axiomatic that an incumbent usually begins the race with significant advantages. . . . Where the incumbent has the support of major specialinterest groups . . . and is further supported by the media, the overall effect of the contribution and expenditure limitations enacted by Congress could foreclose any fair opportunity of a successful challenge.

Id. The Court never reached this issue, however, because it decided that the expenditure limitations were unconstitutional under the first amendment. Id. 39-59.

If the Court's footnote is read narrowly to the effect that a facially nondiscriminatory campaign financing provision will withstand equal protection scrutiny unless it limits both contributions and expenditures, $\$ 401(\mathrm{~g})$ appears constitutional. But such a narrow reading is illogical. The Court had already declared the campaign-expenditure limitations unconstitutional on first amendment grounds. The footnote would thus be superfluous unless it is read more generally to suggest that, under some circumstances, a facially nondiscriminatory provision might violate the equal protection clause. Under such a reading, $\$ 401(\mathrm{~g})$ is problematic.

147101 L.R.R.M. 2195 (N.D. Ohio), aff'd, 611 F.2d 645 (6th Cir. 1979). 148 See 611 F.2d at 650 .

14929 U.S.C. $\$ 411(\mathrm{a})(4)(1976)$. 
participating in suits by union members against their union or its officers. ${ }^{150}$ The addition of the word "interested" to this proviso was explained in the legislative history: some congressmen feared that without it, union members would be unable to obtain funds from their friends, from banks, or from similar sources. ${ }^{151}$ The union argued that the same rationale should apply to section 401 (g); heeding Professor Cox's admonition, ${ }^{152}$ the union proposed that the word "interested" be read into the provision. ${ }^{153}$

The Sixth Circuit declined to accept this suggestion. Instead, it asserted that "[t] he careful consideration given to the precise wording of $\S 101(a)(4)$. . . in its use of the term interested employer' shows that Congress deliberately decided not to distinguish between interested and disinterested employers in [section $401(\mathrm{~g})$ ] ...." 164

This position is untenable. ${ }^{155}$ The court misconstrued the legislative history of section $401(\mathrm{~g})$ to produce a result which, if followed to its logical conclusion, is facially absurd. ${ }^{156}$ Further, by attempting to draw a line which would be easy to apply, the court created a host of new problems, thus confounding that purpose. ${ }^{157}$ Finally, a literal construction of "employer" would contradict the usually flexible judicial interpretation of the LMRDA. ${ }^{15 s}$

The reason for the broad statutory definition of "employer" 159 is unrelated to Congress's concern with elections; the definition was designed in conjunction with the LMRDA's management reporting provisions. ${ }^{160}$ There is no indication in the legislative history that disinterested employers were disrupting the election process. On the contrary, in Congress's eyes, those employers who engaged in

$150 \mathrm{Id}$. See notes $179-89$ infra \& accompanying text.

151 See, e.g., 105 CoNG. REC. 6725 (1959) (remarks of Sen. Javits), reprinted in II LEGIs. Hist., supra note 9, at 1237; 105 CoNG. REc. 19,758 (1959) (remarks of Sen. Goldwater), reprinted in II LEGIS. Hrst., supra note 9, at 1843, 1844, also reprinted in Goldwater, Legislative History, supra note 79 , at 35 . See also note 167 infra.

152 See text accompanying note 46 supra.

153 See 611 F.2d at 652 .

154 Id. (footnote omitted).

155 The court's view on the "interested employer" issue was also not necessary in order to reach the result of Local 20. See note 31 supra.

156 See notes 171-74 infra \& accompanying text.

157 See notes $175-78$ infra \& accompanying text.

158 See notes 190-98 infra \& accompanying text.

159 LMRDA, $\$ 3(e), 29$ U.S.C. $\$ 201$ (e) (I976).

100 See Rezler, The Definitions of LMRDA, in SYMposIuM on LMRDA 263, 264 (R. Slovenko ed. 1961) [hereinafter cited as Rezler, Definitions]. 
collusion with unions were quite "interested." 161 As the district court in Hodgson v. Liquor Salesmen Local $2{ }^{162}$ stated: "Employers were included [in section $401(\mathrm{~g})$ ] because, as the hearings before the Congress disclosed, 'They (some employers) have cooperated with and even aided crooks and racketeers in the labor movement at the expense of their own employees . . . ."163

Further, the argument that inclusion of the qualifier "interested" in section $101(a)(4)$ implies exclusion of that same limitation from section $401(\mathrm{~g})$ is refuted by careful examination of title IV's history. ${ }^{164}$ Section 401 (g) was a nonpartisan, noncontroversial provision which first passed the Senate over one year prior to enactment of the LMRDA. ${ }^{165}$ Section 101(a)(4), in contrast, was part of a later,

161 See MCClextan CoMm. ReP., supra note 2, at 4-5. This report lists six ways in which management colluded with unions:

(a) They have paid high union officials to obtain favored treatment by way of "sweetheart" contracts.

(b) They have paid off to obtain inferior contracts which impose substandard working conditions on thousands of workers.

(c) They have connived with "approved" unions at under-the-table agreements to permit organizing of their workers to the exclusion of other unions.

(d) Certain companies have granted business concessions and loans to union leaders with whom they want to curry favor.

(e) Trade associations have conspired with unions to achieve industry monopolies.

(f) So called "whip companies" have been set up to keep rival companies in line, and have been blinked at by unions even when they have themselves broken union rules.

Id.

162334 F. Supp. 1369 (S.D.N.Y.), aff'd, 444 F.2d 1344 (2d Cir. 1971).

163 Id. 1380 (quoting SenATE LaBor CoMnc. ReP., supra note 9, at 6, reprinted in [1959] U.S. CoDE CoNG. \& AD. News 2318, 2336, also reprinted in I LEGIS. Hist., supra note 9, at 402) (emphasis added) (court's omission). The Sixth Circuit in Marshall v. Local 20 , Int'l Bhd. of Teamsters quoted this passage with approval in its first amendment discussion. 611 F.2d at 653.

164 See generally Rezler, Elections, supra note 1, at 489-94.

165 Section 401 (g) was originally part of the Kennedy-Ives bill, S. 3974, 85th Cong., 2d Sess., 104 Cong. REc. 18,260-66 (1958). The Kennedy-Ives bill passed the Senate by a vote of 88-1, 104 Cong. REc. 11,486-87 (1958), but died in the House in an election year. See, e.g., J. BexxACE, supra note 5, at 4-5; Levitan, supra note 47 , at $42-45$. Although parts of the bill, like parts of the LMRDA, generated controversy on the Senate floor, the Senate did not discuss the precursor of $\$ 401(\mathrm{~g})$. (The Senate floor debate took place from June 12-17, 1958, and is interspersed throughout 104 CoNG. REc. 10,943-11,487 (1958).)

In the next Congress, rival bills were introduced in the House as substitutes for the Kennedy-Ervin bill already enacted by the Senate. Insofar as these bills mentioned contributions to union elections, they were identical to $\$ 401(\mathrm{~g})$. E.g., H.R. 8342, $\$ 401$ (f), 86th Cong., 1st Sess. (1959) (Elliot bill), reprinted in I LEors. Hist., supra note 9 , at 687,726 ; H.R. 8400, $\$ 401(f), 86$ th Cong., 1st Sess. (1959) (Landrum-Griffin bill), reprinted in I LeGrs. HIST., supra note 9 , at 619,656 ; H.R. $8490, \S 401(f), 86$ th Cong., Ist Sess. (1959) (Shelley bill), reprinted in I Lears. HIst., supra note 9 , at 865,906 . See also S. 748, $\$ 303$ (a)(1), 86th Cong., Ist Sess. (1959) (administration bill), reprinted in I LEGIs. HIST., supra note 9 , at 84 , 113-14. 
controversial amendment to the Act. ${ }^{166}$ Thus, the presence of the word "interested" in section 101(a)(4) ${ }^{167}$ can hardly shed any light on the congressional intent with respect to the earlier section. The most likely explanation of the difference between sections $101(a)(4)$ and $401(\mathrm{~g})$ is simply that title IV was overlooked ${ }^{168}$ in the controversy surrounding titles I and VII over which most of the legislative battles were fought. ${ }^{169}$

A continued mechanical reading of "employer" will lead to an absurd result-some union members might be barred from making contributions in union elections. ${ }^{170}$ Section 3(e) of the LMRDA defines "employer" to include anyone in "an industry affecting com-

160 After the Senate bill was reported out of committee, title I was introduced on the Senate floor in "an impassioned two-hour speech" by Senator McClellan. J. BELLACE, supra note 5, at 6; see 105 CoNG. Rec. 6469-80 (1959), reprinted in II LEGIS. Hrst., supra note 9, at 1096-1108.

167 The interested-employer proviso was not part of Senator McClellan's proposal; it was added in a subsequent floor amendment to the bill. See 105 Covg. Rec. 6724-27 (1958), reprinted in II LEGrs. Hrst., supra note 9, at 1236-39. See generally, e.g., 105 CoNG. Rec. 19,758 (1959) (remarks of Sen. Goldwater), reprinted in II LEGIs. Hrst., supra note 9 , at 1843, 1844, also reprinted in Goldwater, Legislative History, supra note 79, at 35; Rothman, Legislative History of the "Bill of Rights" for Union Members, 45 MINN. L. Rev. 199, 213-16 (1960).

168 Even when title IV was discussed, congressmen and commentators alike frequently overlooked the prohibition against employer, as opposed to union, contributions in $\$ 401(\mathrm{~g})$ or identical provisions of other bills. See, e.g., SENATE LABOR COMM. ReP., supra note 9, at 4, reprinied in [1959] U.S. Code Cong. \& AD. NEws 2318, 2320, also reprinted in I LEGrs. Hist., supra note 9 , at 400; H.R. REP. No. 741, 86th Cong., 1st Sess. 3, reprinted in [1959] U.S. CODE Cong. \& AD. News 2424, 2426, also reprinted in I LEGrs. Hrst., supra note 9, at 759, 761; 105 ConG. Rec. 885 (1959) (remarks of Sen. J. Kennedy), reprinted in II LEGrs. Hist., supra note 9, at 969; 105 CoNG. REc. 1450 (1959) (remarks of Rep. J. Roosevelt), reprinted in II Legis. Hrst., supra note 9, at 1464; 105 Cong. REc. 6741 (1959) (remarks of Sen. Mundt), reprinted in II LeGrs. Hrst., supra note 9, at 1253-54; 105 CoNG. REc. 15,021 (1959) (remarks of Rep. J. O'Hara), reprinted in II LEGIS. Hist., supra note 9, at 1535; 105 CoNG. Rec. 15,549 (1959) (explanation by Rep. Elliot, quoted in remarks of Rep. Bolling), reprinted in II LEGIs. Hrst., supra note 9, at 1585; 104 CoNG. REc. 11,481 (1958) (statement of Sen. McClellan, quoted in remarks by Sen. Johnson); Cox, supra note 4, at 844; Daniels, Union Elections and the Landrum-Grifin Act, 13 N.Y.U. CoNF. LAB. 317, 318-24 (1960); Lipset, supra note 24, at 24 (1961); Summers, supra note 63, at 294; Note, The Election Labyrinth, supra note 145, at 348-50; Comment, Union Corruption, supra note 1, at 486; Note, The Kennedy-Ives Bill: An Analysis of Suggested Labor Legislation, 107 U. PA. L. REv. 685, 692 (1959).

169 Title I passed by a vote of $47-46$, and escaped reconsideration by a vote of 46-45, with Vice President Nixon casting the tie-breaker. 105 Cong. REc. 6492 (1959), reprinted in II LEGIS. HrsT., supra note 9, at 1119. See J. BeLLACE, supra note 5, at 6; Griffin, supra note 64, at 28; Murphy, The Background of the Bill of Rights and Its Provisions, in SYMPOSTuM, supra note 1, at 277, 281-83.

Title VII contained controversial amendments to the secondary-boycott provisions of the National Labor Relations Act, and much of the debate on the LMRDA "raged" around these changes. Griffin, supra note 64 , at 27. See J. BELLAcE, supra note 5 , at 5,7 .

Title IV, however, was enacted with comparatively little debate or amendment. See, e.g., J. BeLlaCE, supra note 5, at 7; Rezler, Elections, supra note 1, at 491-92.

170 Note that inferring the qualifier "interested" into $\$ 401(\mathrm{~g})$ 's proscription of employer contributions does not solve the problem of the union-member employer 
merce" who is an employer "within the meaning of any law . . . relating to the employment of any employees." 171 This definition obviously includes a union member who operates a small business on the side. If broad enough interpretations are given to "industry affecting commerce" 172 and "any law," 173 the term "employer" would encompass union members who employed a nurse, maid, or even a babysitter. ${ }^{174}$ Of course, the courts would not adhere to the mechanical reading of "employer" described above. Sooner or later they must grapple with both of the LMRDA's underlying rationales; the purposes of the Act are best effectuated by applying its policies sooner.

It is, however, tempting to avoid these policy issues. By refusing to read "interested" into section 401 (g), the courts may believe they have devised a test capable of easy application. ${ }^{175}$ In one sense, an all-inclusive definition of the term "employer" is quite efficientit does save the time necessary to define the term "interested." But this is false economy; such a definition creates new problems without really avoiding the old one. A new series of questions emerges: Are donations of legal services from disinterested employers to candidates barred by section 401 (g) or saved by section $101(\mathrm{a})(4)$ ? ${ }^{176}$ If the former, does section 401 (g) violate the first amendment? ${ }^{177}$ And, in a different vein, is nondiscriminatory publicity by an employer illegal? ${ }^{178}$

-by any reasonable definition he will be "interested." See notes 179-89 infra \& accompanying text.

17129 U.S.C. $\$ 402(e)$ (1976) (emphasis added). See generally Rezler,

Definitions, supra note 160, at 264-65.

172 See, e.g., Rezler, Definitions, supra note 160, at 265.

173 See, e.g., I.R.C. $\$ 3306$ (a) (withholding statute); 29 U.S.C. $\$ 203$ (d)

(1976) (Fair Labor Standards Act).

174 See Rauh, supra note 6.

175 Local 20, 101 L.R.R.M. at 2197.

$176 \mathrm{See}$ UAW v. National Right to Work Legal Defense \& Educ. Foundation, Inc., 590 F.2d 1139, 1150 (D.C. Cir. 1978), aff'g 433 F. Supp. 474 (D.D.C. 1977) ( $\$ 104$ (a) (4) does not prohibit legal services from bona fide legal-aid organization). In McBride v. Rockefeller Family Fund, 101 L.R.R.M. 2576 (S.D.N.Y.), aff'd, 612 F.2d 34 (2d Cir. 1979), cert. denied, 48 U.S.L.W. 3626 (U.S. March 3I, 1980), the Steelworkers claimed that free legal services constituted illegal employer contributions. Complaint at 9-10. The case was decided against the union on jurisdictional grounds, but the complaint demonstrates that the question posed in the text is not hypothetical.

177 In UAW v. National Right to Work Legal Defense \& Educ. Foundation, Inc., the district court held that $\S 101(\mathrm{a})(4)$ contained such a prohibition and therefore violated the first amendment. $433 \mathrm{~F}$. Supp. at 482 . The District of Columbia Circuit, partly to avoid the constitutional question, $590 \mathrm{~F} .2 \mathrm{~d}$ at $1147-48$, held that $\oint \operatorname{lol}(\mathrm{a})(4)$ "does not apply to legitimate activity of a bona fide, independent legal organization." Id. 1150.

178 Nondiscriminatory publicity by a union is legal, even though one-sided publicity is a contribution. See note 201 infra. It is difficult to justify construing employer publicity differently. 
The old problem-defining "interested"-remains, because the courts nonetheless must reach this issue in the context of section 101(a) (4). The cases construing this section demonstrate that it is possible to devise a manageable definition of "interested employer." 179 Under section 101(a)(4), an employer's "interest" has been held to stem from his relationship with the union, ${ }^{180}$ or from his stake in the litigation. ${ }^{181}$ In Adamszewski v. Local 1487, International Association of Machinists, ${ }^{182}$ the employer was held to be "interested" because "any divisiveness within the union [caused by the suit] . . . could weaken it at the bargaining table where it would be unable to present a solid front." 183 Adamszewski also held that an employer who was "liable to be affected by" the litigation was "interested." 184 On the other hand, an independent legalaid organization having no relationship to the union was not "interested," even though the organization received contributions from interested employers. ${ }^{185}$

These interpretations are certainly adaptable to section $401(\mathrm{~g}){ }^{186}$ An employer may contribute to a campaign unless he is in an actual or potential bargaining relationship with the union, or

179 See Harris v. Plasterers Local 406, 103 L.R.R.M. 2884 (7th Cir. March 10, 1980); UAW v. National Right to Work Legal Defense \& Educ. Foundation, Inc., 590 F.2d 1139 (D.C. Cir. 1978); Adamszewski v. Local 1487, Int'l Ass'n of Machinists, 496 F.2d 777 (7th Cir.), cert. denied, 419 U.S. 997 (1974); Farowitz v. Associated Musicians Local 802, 241 F. Supp. 895 (S.D.N.Y. 1965). See generally J. BELLACE, supra note 5, at 63-66; see also IBEW Local $336 \mathrm{v}$. Illinois Bell Tel. Co., 496 F.2d 1, 3-4 (7th Cir.), cert. denied, 419 U.S. 879 (1974) (interested employer may finance employee's defense or counterclaim); UAW v. Oshkosh Truck Corp., 96 L.R.R.M. 2866 (E.D. Wis. 1977) (complaint states claim on which relief under $\$ 101(\mathrm{a})(4)$ can be granted).

180 See Harris, 103 L.R.R.M. at 2887 (quoting Adamszewski, $496 \mathrm{~F} .2 \mathrm{~d}$ at 783). 181 See Harris, 103 L.R.R.M. at 2887 (quoting Adamszetwski, 496 F.2d at 784); J. BELLACE, supra note 5 , at 64 .

182496 F.2d 777 (7th Cir.), cert. denied, 419 U.S. 997 (1974).

183 Id. 784.

An early case, Farowitz v. Associated Musicians Local 802, 241 F. Supp. 895 (S.D.N.Y. 1965), held that employers in a sporadic collective bargaining relationship were not "interested" because of their small, indirect interest, where what was at stake for the plaintiff was "his career and livelihood." Id. 908. While Adamszewski distinguished Farowitz, the Adamszewski court also said that the Farowitz reading of the purposes of $\$ 101(\mathrm{a})(4)$ was too narrow. 496 F.2d at 782 . Thus, the Farowitz result now appears to be appropriately rejected.

184496 F.2d at 784.

185 UAW v. National Right to Work Legal Defense \& Educ. Foundation, Inc., 590 F.2d 1139, 1150-51 (D.C. Cir. 1978).

186 The $\oint 10 I(a)(4)$ interpretations are not facially inconsistent with the language of the Department of Labor regulation: "The prohibition [of $\$ 401(\mathrm{~g})$ ] ... is not restricted to employers who employ members of the labor organization ... or who have any business or contractual relationship with the labor organization." 29 C.F.R. $\$ 452.78$ (b) (1979). The definition in the text is sufficiently broad and therefore contains no such restriction. 
unless "the factual context" 187 shows that the employer could potentially realize "legal, financial or business advantage" 188 from the election. Thus, any business or bargaining relationship, either actual or potential, would be sufficient to disqualify an employer from contributing to an internal union election. ${ }^{189}$

Such a reading of section 401 (g) comports with the long history of judicial flexibility in construing the LMRDA. In Hall v. Cole, ${ }^{190}$ for example, the Supreme Court held that counsel fees should be awarded to the plaintiff in a section $102{ }^{191}$ suit, even absent explicit statutory authorization. The defendants in the case argued that because Congress had expressly authorized fee-shifting in sections $201(c)^{192}$ and 501(b), ${ }^{193}$ the lack of a similar provision in section 102 "indicates an intent to preclude 'fee-shifting." 194 The Court, citing Professor Cox's advice to the judiciary, ${ }^{195}$ rejected this argument.

The Court followed the same approach in Wirtz ข. Local 153, Glass Bottle Blowers Association, ${ }^{196}$ a title IV case. Despite the statute's clear and unambiguous language, the Court felt compelled to look beyond mere words to the policies underlying the LMRDA:

$[\mathrm{N}] \mathrm{o}$ exceptions are admitted by the unambiguous wording....

Nonetheless, this does not end the inquiry. We have cautioned against a literal reading of congressional labor legislation; such legislation is often the product of conflict and compromise between strongly held and opposed views, and its proper construction frequently requires consideration of its wording against the background of its legislative history and in the light of the general objectives Congress sought to achieve. . . . The LMRDA is no exception. ${ }^{107}$

187 Harris, 103 L.R.R.M. at 2887 (quoting Adamszewski, 496 F.2d at 784). 188 Adamszewski, 496 F.2d at 784.

189 See James, supra note 5, at 282-83, 291-93. A rule broader than that proposed by this Comment, yet narrower than the present judicial interpretation, would bar contributions from business or corporate entities and their major stockholders. See Rauh, supra note 6.

190412 U.S. 1 ( 1973 ).

191 LMRDA, $\$ 102,29$ U.S.C. $\$ 412$ (1976).

192 Id. $\$ 201(c), 29$ U.S.C. $\$ 431$ (c) (1976).

193 Id. $\$ 501$ (b), 29 U.S.C. $\$ 501(\mathrm{~b})$ (1976).

194412 U.S. at 10.

195 Id. 11 n.17. See text accompanying note 46 supra.

196389 U.S. 463 (1968).

197 Id. 468 (citing Cox, supra note 4, at 852) (citations and footnote omitted). 
Application of these principles of flexible judicial construction leads inexorably to the conclusion that the term "employer" must be construed narrowly.198 Further, the very structure of section $40 \mathrm{I}(\mathrm{g})$ demonstrates that the legislators who drafted it were unaware of the enormous disparities between incumbent and challenger. ${ }^{109}$ Congressional incomprehension ${ }^{200}$ of the setting in which section 401 (g) operates, however, is no justification for judicial ignorance. ${ }^{201}$ In this connection, it is significant that when Congress did see financial imbalance, in the section 101(a)(4) suit by the individual against his union, it carefully delineated an acceptable funding source for the needy plaintiff-the disinterested employer.

Judicial reinterpretation of section $401(\mathrm{~g})$ has merit. First, and most important, the proposal opens a crack in the financing scheme, enabling the challenger to obtain sufficient funding in a union election. This will foster one of the LMRDA objectives:

198 See notes 56-77 supra \& accompanying text.

199 See text accompanying notes 112-22 supra.

200 Legislative ignorance was spotted early. Shortly after the bill was passed, one commentator noted:

It is the crippling weakness of the new labor law that, while prescribing

free traffic for dissenting opinion, it does not provide the means for advancing the views or interests of a dissenting member or group. There is a drastic disparity between the material and other resources at the disposal of an officer defending himself-and the union-and the sinews of war available to the individual member. The authors of LMRDA, nearly all lawyers, might have given this some thought, but they did not. Hardman, Labor Courts for Labor Democracy, New Leader, Jan, 25, 1960, at 20, 21.

201 For an impressive example of a court sufficiently ambitious to look beyond legislative ignorance, see Yablonski v. UMW, 305 F. Supp. 876, 877 \& n.1 (D.D.C. 1969) (supplementing 305 F. Supp. 868 (D.D.C. 1969)) (union newspaper could devote equal space to both candidates without violating $\$ 401(\mathrm{~g})$, even though Congress had not considered that option when the provision was drafted).

NLRB Member Jenkins has also stated that nondiscriminatory coverage of candidates, though literally in violation of $\$ 401(\mathrm{~g})$, should be deemed legal:

It has become the fashion for many unions having newspapers or other publications to adopt what has come to be known as a "battle page." The paper opens its columns to all candidates and permits each or his adherents to submit copy for publication without revision of content aside from libel. Others follow the practice of publishing profiles or summaries concerning all candidates, permitting the candidate to approve what is said about him. Neither of these practices, though technically constituting use of union funds for statements involving candidates, has been deemed violative of Section $401(\mathrm{~g})$. This construction is thought to be both realistic and consistent with the legislative history of the statutory provision.

Jenkins, supra note 102 , at 172 .

This approach is now embodied in regulations of the Department of Labor. 29 C.F.R. $\$ \S 452.74-.75$ (1979). These rules expressly authorize expenditure of union funds for "impartial" election publicity, such as sponsoring debates for all candidates and distributing biographical data of all candidates. Id. $\$ 452.74$. The only explicitly probibited use of union newspapers is for a "showing of preference." Id. $\$ 452.77$. 
ensuring responsive leadership. Second, the addition of the word "interested" will work as a bar against unscrupulous employers looking for deals and favors. Thus, the second objective of the LMRDA-preventing corruption-will be satisfied as well. ${ }^{202}$ Third, the solution is judicially created and can therefore be implemented immediately by the courts. ${ }^{203}$

\section{B. Legislative Proposals}

In the long run, the judicial authorization of disinterested employer contributions is an unsatisfactory and indirect solution to a deep-rooted problem. The rule requires close supervision by the courts, and is concededly more difficult to administer than a flat ban on all employer funding. ${ }^{204}$ It boosts the expenditure level of all candidates-not merely the challenger. Even more important, the acceptance of outside funding by the challenger provides ammunition for the incumbent, who is eager to paint his adversary as an agitator, outsider, or traitor. ${ }^{205}$ In such a setting, the challenger's dependence on outside money is, at best, problematic.

A more effective approach to the problems inherent in unionelection financing would aim directly at the source of the trouble-

202 This objective is also furthered by the reporting and disclosure requirements located in title II of the LMRDA, $\$ \$ 201-211,29$ U.S.C. $\$ \$ 432-433$ (1976), and by $\$ 302(a)(4)$ of the Labor Management Relations Act, 29 U.S.C. $\$ 186(a)(4)$ (1976), which makes it unlawful, inter alia, for any employer or employer association to give any money or other thing of value "to any officer or employee of a labor organization . . . with intent to influence him in respect to any of his actions, decisions, or duties as a representative of employees or as such officer or employee of such labor organization." Id.

203 One final advantage to this approach is its skirting of the first amendment issue raised by the defendant union in Marshall $v$. Local 20, Int'l Bhd. of Teamsters. See text accompanying note 34 supra and note 41 supra \& accompanying text. A discussion of the relevant constitutional considerations would be inappropriate here, but the interested reader is urged to compare Buckley v. Valeo, 424 U.S. 1 (1976) (holding that a federal limitation on campaign contributions "permits the symbolic expression of support evidenced by a contribution but does not in any way infringe the contributor's freedom to discuss candidates and issues." Id. 21) with UAW v. National Right to Work Legal Defense \& Educ. Foundation, Inc., 433 F. Supp. 474,483 (D.D.C. 1977), aff'd on other grounds, 590 F.2d 1139 (D.C. Cir. 1978) (district court held that interested-employer proviso of $\$ 101(\mathrm{a})(4)$, as applied to the foundation, violated the first amendment rights of the foundation and its contributors).

204 See note 109 supra \& accompanying text.

205 See, e.g., Sheldon v. O'Callaghan, 335 F. Supp. 325, 326 n.2 (S.D.N.Y. 1971) (union newsletter referred to opposition as "flunkies, character assassins, racists and finks who pollute the waterfront with propaganda against the leadership ... with mindless, poison pen, libelous anti-labor trash. . . Groups and cliques who spread the garbage suck the curdled milk from the mother wolf who inspires the wolf-pack."). See generally J. BARBASH, supra note 70, at 13I; James, supra note 5 , at $281-82$; text accompanying note 75 supra. 
the union staff. 200 This Comment has demonstrated that the union staff is a powerful force in engineering the re-election of the incumbent. $^{207}$ New legislation, patterned after the Hatch Act, ${ }^{208}$ could go far in correcting this imbalance. ${ }^{209}$ The Hatch Act forbids federal government employees from giving or receiving any "thing of value for political purposes," 210 and prevents them from "tak[ing] an active part in political management or in political campaigns." 211 The similarities between the abuses rectified by the Hatch Act and the abuse still extant in the labor movement are striking:

[T] ]he immediate occasion for enactment of the Hatch Act in 1939 . . . was the conviction that the rapidly expanding Government work force should not be employed to build a powerful, invincible, and perhaps corrupt political machine. The experience of the 1936 and 1938 campaigns convinced Congress that these dangers were sufficiently real that substantial barriers should be raised against the party in power-or the party out of power, for that matter-using the thousands or hundreds of thousands of federal employees, paid for at public expense, to man its political structure and political campaigns. ${ }^{212}$

A legislative amendment to the LMRDA which limited the power of the union staff "to build a powerful, invincible, and per-

206 The proposals sketched in this section are not meant to be the final word. Instead, it is hoped that these rather broad suggestions will stimulate future discussion.

207 See notes 112-30 supra \& accompanying text.

$208 \mathrm{Ch} .410,53$ Stat. 1147 (codified in scattered sections of 5, 18 U.S.C.). 209 The discussion in the text following this note is not meant to suggest that an amendment to the LMRDA patterned after the Hatch Act is imminent. In fact, significant congressional hostility to the Hatch Act has arisen in recent years. In 1976, for example, both the House and Senate passed legislation watering down the strictures of the Hatch Act considerably. 122 Conc. Rec. 8549 (1976) (House passage); id. 8850 (Senate passage). The House's attempt to override President Ford's veto fell only 26 votes short. Id. 11,867.

The discussion does demonstrate, however, that the same policies which originally led Congress to enact the Hatch Act are also present in the union-election setting today. And these policies-stemming from the power relationships between employer and employee-continue to concern Congress despite its hostility to the Hatch Act itself. For example, even the 1976 legislation would have prohibited both outright coercion of employees by employers and "solicitation of political contributions by superior officials." 122 CoNG. REC. 8543 (1976) (remarks of Rep. Clay). Thus, congressional hostility to the Hatch Act will not necessarily carry over into the union setting.

2105 U.S.C. $\$ 7323$ (1976).

211 Id. $\$ 7324(\mathrm{a})(2)$.

212 United States Civil Serv. Comm'n v. National Ass'n of Letter Carriers, 413 U.S. 548, 565-66 (1973) (citations omitted). See also notes 132 \& 133 stpra \& accompanying text. 
haps corrupt political machine" 213 would undoubtedly aid the development of union democracy. ${ }^{214}$ But it is not a panacea. It would do nothing, for instance, to further the political career of an ambitious, but penniless rank-and-file challenger. Without funds, the challenger is no match for any incumbent-whether or not the union staff is neutralized. Thus, this Comment also proposes that the unions themselves be encouraged to finance-in a nondiscriminatory fashion-the political campaigns of any "bona fide" candidate. This idea has been applied on a limited basis already ${ }^{215}$ - the "candidates page" in the union newspaper is a good example 216 -but it should be legitimated and broadened in new legislation which authorizes the use of union money as a major campaign resource.

The inadequacy of resources that plagues the rank-and-file challenger is not unique to union elections. The problem recurs in many contexts, and the solution most frequently proposed is a form of institutionalized funding. In the public arena, for example, government subsidies ${ }^{217}$ are often used to ensure some balance between incumbent and challenger. ${ }^{218}$ An even more striking parallel can be found in the corporate context. The movement toward "corporate democracy" in the 1950's forced both courts ${ }^{219}$ and commentators ${ }^{220}$ to confront the financial disparity between the

213413 U.S. at 565.

214 But see Thirteen Years of Use, supra note 76, at 467-68 (suggesting that the service staff should not be depoliticized, proposing instead that service-staff positions be made elective).

215 See note 201 supra.

216 See Yablonski v. UMW, 305 F. Supp. 876 (D.D.C. 1969) (supplementing 305 F. Supp. 868 (D.D.C. 1969)); note 201 supra.

217 See, e.g., I.R.C. $\$ \$ 6096,9001-9013,9031-9042$ (authorization of subsidies from a special fund to eligible candidates in United States presidential primaries and elections). These provisions were upheld in Buckley v. Valeo, 424 U.S. I, 86-109 (1976).

218 See, e.g., Nicholson, Campaign Financing and Equal Protection, 26 STAN. L. Rev. 815 (1974), in which the author proposes the use of substantial campaign subsidies to improve the challenger's position vis-à-vis the incumbent. The author notes that subsidies would "aid both the incumbent and the challenger, but the incumbent may have already reached a point of diminishing returns with his or her public exposure, whereas an unknown opponent may be given a substantial boost by such an opportunity." Id. 848. See generally A. HEARD, TrE Costs of DEMocracy 431-37 (1960); Agree, Public Financing after the Supreme Court Decision, 425 ANNArs 134 (May 1976); Biden, Public Financing of Elections: Legislative Proposals and Constitutional Questions, 69 Nw. U. L. REv. I (1974); Fleischman, Public Financing of Election Campaigns: Constitutional Constraints on Steps Toward Equality of Political Influence of Citizens, 52 N.C. L. REv. 349 (1973).

219 See, e.g., Steinberg v. Adams, 90 F. Supp. 604 (S.D.N.Y. 1950); Rosenfeld v. Fairchild Engine \& Airplane Corp., 309 N.Y. 168, 128 N.E.2d 291, 148 N.Y.S.2d (1955).

220 See, e.g., F. Emerson \& F. Latcham, Shareholder Democracy (1954); Emerson \& Latcham, Proxy Contests: A Study in Shareholder Sovereignty, 4I Car.r. L. REv. 393 (1953) [hereinafter cited as Emerson]; Friedman, Expenses of 
entrenched incumbent management, which had full access to the corporate proxy machinery, 221 and the insurgent minority shareholder, who fought his proxy battles alone. ${ }^{222}$ In the corporate area, courts have used a "common benefit" theory to hold successful insurgents entitled to reimbursement by the corporation after the "campaign." 223

There is already precedent for extending the "common benefit" theory from corporate to labor law; it has been applied in LMRDA section $102{ }^{224}$ suits to justify union payments of members' attorney's fees. ${ }^{225}$ Although these cases concern litigation, not election, expenses, many of the same considerations apply. As the court in Hall v. Cole noted:

Corporate Proxy Contests, 51 CoLom. L. REv. 951 (1951); Note, Corporations: Proxy Solicitation and the Payment of Expenses Incurred by Insurgent Shareholders Out of Corporation Funds, 36 ConNexl L.Q. 558 (1951) [hereinafter cited as Proxy Solicitation]; Comment, Proxy Contests: Corporate Reimbursement of Insurgents' Expenses, 23 U. CEr. L. Rev. 682 (1956) [hereinafter cited as Proxy Contests]; Note, Proxy Solicitation Costs and Corporate Control, 61 YALE L.J. 229 (1952) [hereinafter cited as Proxy Costs].

221 Corporate office-holders, bound by their fiduciary duty to the corporation, may not use corporate funds merely to perpetuate themselves in office, but may use the corporate proxy machinery if (1) the contest involves a policy issue; (2) the corporate funds are used to inform the shareholders about the policy issues; and (3) the expenses are reasonable. Eisenberg, Access to the Corporate Proxy Machinery, 83 HaRv. L. REv. 1489, 1496 (1970).

222 Perhaps the best example of an effort to equalize the financial positions of the individual shareholder and management is SEC rule 14a-8, 17 C.F.R. \$240.14a-8 (1979). That Securities and Exchange Commission regulation requires management to include in its proxy statement certain shareholder proposals at no cost to the individual shareholder. The provision is of limited relevance to this discussion, however, because proposals relating to an election need not be included. Id. $14 a-8(c)(8), 17$ C.F.R. $\$ 240.14 a-8$ (c) (8) (1979).

223 See Steinberg v. Adams, 90 F. Supp. 604, 607-08 (S.D.N.Y. 1950) (Shareholders may reimburse insurgents who, after their election, succeed "in ridding a corporation of a policy frowned upon by a majority of the stockholders."); Rosenfeld v. Fairchild Engine \& Airplane Corp., 309 N.Y. 168, 173, 128 N.E.2d 291, 293, 148 N.Y.S.2d (1955) (shareholders who sued derivatively for "reasonable" sums paid by corporation to successful insurgents for expenses incurred in proxy fight, denied recovery).

Several commentators have extended this argument and taken the position that unsuccessful insurgents also deserve reimbursement under a "common benefit" theory. See, e.g., E. Aranow \& H. Ennerorn, Proxy Contests for Corporate ConTrol 575-77 (2d ed. 1968) [hereinafter cited as E. ARANow]; Friedman, supra note 220, at 958; Comment, Proxy Contests, supra note 220, at 690; Note, Proxy Costs, supra note 220, at 235. Contra, Note, Proxy Solicitation, supra note 220, at 563-64.

22429 U.S.C. $\$ 412$ (1976).

225 See, e.g., Hall v. Cole, 412 U.S. 1, 8 (1973) (Successful plaintiff in suit against union can be awarded attorney's fees because "by vindicating his own right, the successful litigant dispels the "chill" cast upon the rights of others."); notes 190-95 supra \& accompanying text. Cf. Brennan v. United Steelworkers, 554 F.2d 586 (3d Cir. 1977) (insurgent candidate who, after losing election for district director, intervened in Secretary of Labor's suit to overturn the election, may be entitled to attorney's fees under "common benefit" rule). 
Not to award counsel fees in cases such as this would be tantamount to repealing the Act itself by frustrating its basic purpose. It is difficult for individual members of labor unions to stand up and fight those who are in charge. The latter have the treasury of the union at their command and the paid union counsel at their beck and call while the member is on his own. . . An individual union member could not carry such a heavy financial burden. Without counsel fees the grant of federal jurisdiction is but a gesture for few union members could avail themselves of it. ${ }^{226}$

The considerations expressed in this Comment confirm the need for union subsidization of its own election campaigns. Such funding would lessen the importance of disparities in resources, and could go far towards creating and maintaining some balance between incumbent and challenger. The availability of union funds would also decrease the incentives to solicit contributions from outsiders, thereby strengthening notions of union autonomy.

The practical difficulties in implementing such a scheme, however, are formidable. Should union subsidization be a strictly voluntary form of election financing, and, if so, how can it be encouraged? Who would be entitled to funding, and how much money would be allocated to each candidate? Assuming only "bona fide" candidates would receive reimbursement for their "reasonable expenses," how would these terms be defined?

Existing answers to these questions developed in other contexts are not at all satisfactory. For example, the Presidential Election Campaign Fund Act ${ }^{227}$ allocates funds in varying amounts ${ }^{228}$ to candidates in major, minor, and new parties, ${ }^{229}$ but provides no funds for independent candidates. Shareholder reimbursement in the corporate area has produced a flood of proposed solutions. These proposals have ranged from limiting reimbursement to candidates receiving some minimum percentage of the vote, ${ }^{230}$ to pro1972)).

226412 U.S. at 13 (quoting Cole v. Hall, 462 F.2d 777, 780-81 (2d Cir.

227 I.R.C. $\$ \S 9001-9013$.

228 Id. $\$ 9004$.

229 The statute categorizes a party according to the percentage of the total popular vote its presidential candidate received in the prior election. Id. $\$ 9002(6)-(8)$.

230 See, e.g., Friedman, supra note 220, at 963; Comment, Proxy Contests, supra note 220 , at 690 . 
portional reimbursement, ${ }^{231}$ to purely voluntary reimbursement at the corporation's discretion. ${ }^{232}$

Further, these proposed solutions to the inherent problems of institutionalized campaign financing were all formulated in contexts materially different from the union setting. First, permanent parties-major, minor, or otherwise-are not a part of the union political structure. ${ }^{233}$ Thus, any union subsidization plan must guard against frivolous candidacies by individuals who do not represent even a minority of the membership. Second, the concept of "reimbursement" which pervades discussions of corporate democracy is not as appropriate in the union context. The insurgent shareholder who funds a proxy fight with his own resources and expects reimbursement after the fact may be in a better financial position than the rank-and-file challenger who requires subsidization before he can even start campaigning. Finally, one must ask whether any incumbent union leadership would voluntarily adopt such a scheme, and how it would be policed once adopted. Currently, the answers must await serious legislative study.

\section{CoNCLUSION}

The legislative proposals sketched here are concededly roughhewn. There is no indication that any equitable election-financing schemes either exist currently or are likely to be developed in the near future-in the public or private arena. But it is time for the Congress to re-evaluate section 401 (g) of the LMRDA and begin the task of drafting new and better legislation.

At the same time, it is incumbent upon the judiciary to confront the difficulties inherent in the provision as drafted and grapple

231 Two forms of proportional reimbursement are proposed in the literature. The first would compare the votes and expenses of both management and insurgent as follows:

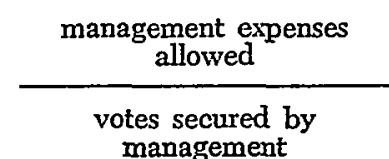

Emerson, supra note 220 , at 436 .

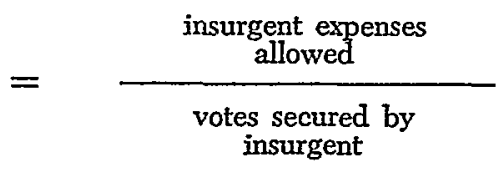

The second proportional reimbursement proposal would rely on the percentage of votes received by the insurgent. For example, any insurgent who receives $50 \%$ of the vote would receive $100 \%$ reimbursement; an insurgent receiving $25 \%$ of the vote, however, would be entitled to only $50 \%$ reimbursement. See Comment, Proxy Contests, supra note 220 , at 690 .

232 The result of such a proposal, in practical terms, would be to provide reimbursement only to successful candidates. Eisenberg, supra note 221, at 1512. 
with them aggressively and imaginatively. The court in Marshall v. Local 20, International Brotherhood of Teamsters ${ }^{234}$ failed to meet this challenge. It is hoped that the next court which examines the problem will look beyond the "plain meaning" of the statute to the even plainer-and harsher-realities of internal-union-election financing.

234101 L.R.R.M. 2195 (N.D. Ohio), aff'd, 611 F.2d 645 (6th Cir. 1979). 